\title{
Navigating trade-offs in land-use planning: integrating human well-being into objective setting
}

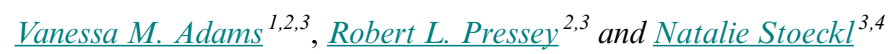

\begin{abstract}
There is an increasing demand for development of natural resources, which can be accompanied by environmental degradation. Planning for multiple land uses requires navigating trade-offs between social, economic, and environmental outcomes arising from different possible futures. To explore these trade-offs, we use the Daly River catchment, in Australia's Northern Territory, as a case study. The catchment contains areas of priority for both conservation and development. In response to the challenge of navigating the required trade-offs, the Daly River Management Advisory Committee (DRMAC) initiated a land-use plan for the region. Both development and conservation of natural resources in the catchment will affect human well-being and the long-term provisioning of ecosystem services in diverse ways. To understand some of these impacts, an innovative engagement process was designed to elicit the relative importance of key factors to residents' well-being. The process identified 19 well-being factors grouped into four domains: biodiversity, socio-cultural, recreational, and commercial. Overall, the highest-ranked well-being factors were in the social-cultural and biodiversity domains while commercial values were ranked the least important. Respondents reported low satisfaction with commercial factors as well, noting concerns over environmental impacts from existing developments and sustainability of future developments. We identified differences in the reported importance values for several types of stakeholders, most notably between indigenous respondents and those employed in the agricultural sectors. Indigenous respondents placed greater importance on biodiversity and socio-cultural factors. Agricultural respondents placed greater importance on commercial factors. The outcomes of our engagement were integrated into DRMAC's process of objective-setting to ensure that objectives for each domain were included in land-use planning. Our results can also anticipate potential conflicts between different stakeholders and changes in well-being associated with different land uses. We describe how our findings will inform the next stages of stakeholder engagement and comment on the utility of such an approach for integrating well-being into objective setting for land-use and scenario planning.
\end{abstract}

Key Words: development; human well-being; land-use planning; objective setting; stakeholder engagement; systematic conservation planning

\section{INTRODUCTION}

Conservation objectives have historically focused on ecological outcomes and relied on available science and expert knowledge (Margules and Pressey 2000), but recent contributions have advanced thinking about objectives to also address social objectives such as livelihoods (Pressey and Bottrill 2009). The shift in systematic conservation planning to consider a broader range of objectives has been accompanied by technical advances in available decision-support tools (e.g., Watts et al. 2009). These advances have facilitated more complex approaches to systematic conservation planning that support more holistic spatial approaches in which multiple uses are considered and planned for explicitly. Studies that consider multiple land uses have demonstrated that potential conflicts can be minimized by explicitly accounting for associated trade-offs (Polasky et al. 2005, 2008, Wilson et al. 2010, Venter et al. 2013).

The push to extend conservation planning to include social and economic considerations reflects a broader recognition that plans need to involve stakeholders throughout the planning process to maximize the likelihood of implementation (Knight et al. 2006). The importance of involving stakeholders will probably increase as plans become more comprehensive by integrating multiple land uses, and thereby expand the complexity of potential socioeconomic values and likely trade-offs that will have to be considered (Tallis et al. 2008, McShane et al. 2011). However, even in conservation planning processes with documented stakeholder participation, engagement still typically focuses on stakeholder values relating to planning products, such as proposed maps of protection, rather than their involvement in setting objectives and measuring potential outcomes against these objectives (e.g., Fernandes et al. 2005, Game et al. 2011, Syakur et al. 2012). A clear gap in approaches to conservation planning is the incorporation of stakeholder values into planning objectives to both direct the plan and measure the outcomes. This level of consultation can be difficult for regional plans that affect large populations with diverse stakeholders and interactions between them.

One approach to more meaningful consultation with stakeholders is through the lens of human well-being. Human well-being and its connection to the environment became widely recognized through the Millennium Ecosystem Assessment (Millennium Ecosystem Assessment 2005). Well-being has been a key framework, in particular, for valuing and managing ecosystem services (e.g., Costanza et al. 1997, Maynard et al. 2010), exploring social preferences (e.g., Malinga et al. 2013), and identifying priorities for policy (for Index of Dissatisfaction measure see Larson 2009, Larson et al. 2013). Although human well-being has received an increased focus by academics, policy makers, and practitioners, an understanding of the links between well-being and the natural environment remains a gap in the science and

${ }^{1}$ Research Institute for the Environment and Livelihoods, Charles Darwin University, ${ }^{2}$ Australian Research Council Centre of Excellence for Coral Reef Studies, James Cook University, ${ }^{3}$ National Environmental Research Program Northern Australia Hub, ${ }^{4}$ School of Business and Cairns Institute, James Cook University 
application of planning (Summers et al. 2012). Studies that explore the relationship between natural resources and well-being are thus timely (e.g., Marans 2003, Costanza et al. 2007, Summers et al. 2012).

Integrating residents' preferences at the outset of a planning exercise via their contributions to objectives could ensure that the plan is well aligned with stakeholder values and therefore more socially acceptable (Knight et al. 2006). Although participatory objective setting has been utilized and explored in the related fields of environmental and land-use change planning, particularly through scenario development and evaluation (e.g., see Salter et al. 2009, de Groot et al. 2010, Malinga et al. 2013), it remains underexplored in systematic conservation planning. In addition, expanding conservation planning to consider multiple land uses requires decisions about potentially competing land uses that can result in variable impacts on different aspects of well-being. This decision process can be supported by methods applied in related fields such as the explicit evaluation of potential trade-offs (Polasky et al. 2008) or collective visioning to explore innovative responses to future changes (Barnaud et al. 2013). Different stakeholders or groups of stakeholders will likely have different preferences associated with plan objectives. As such, conservation planning processes that seek to embed the "values" of people within them will differ depending on the groups of stakeholders involved. In our study, we show how the views of residents can be used within the planning process, noting that the same methodological approach could be used with different stakeholders, e.g., a cross-section of residents at the state or country level. We demonstrate how our approach to integrating stakeholder preferences, through eliciting the relative importance of different well-being factors, can inform both the design and evaluations of land-use scenarios, which are themselves tools for understanding the acceptability of alternative futures for regions.

Here we aim to fill two important gaps in conservation planning: elucidating the relative importance of different well-being factors to stakeholders and the links between these factors and the natural environment; and using the relative importance of different wellbeing factors to inform plan objectives and measure plan outcomes. We use the conceptual framework of human well-being and an associated Index of Dissatisfaction for well-being factors (Larson 2009) to quantify the relative importance of well-being factors to different stakeholders and identify management priorities. We use the data on well-being to inform objectives for a land-use plan in a region with conflicting views about desirable future land uses and a process underway to plan for conservation and development. We also discuss the potential use of such an approach in identifying appropriate indicators in scenario analyses and cumulative impact assessments (Peterson et al. 2003, Weber et al. 2012).

\section{METHODS}

\section{Planning region and process}

The planning region is the whole of the Daly River catchment in the Northern Territory, Australia (Fig. 1). The Daly catchment covers approximately 5.2 million ha, extending from the coastline southwest of Darwin to $250 \mathrm{~km}$ inland. The Daly River and its main tributaries are themselves important conservation features, the Daly being one of northern Australia's largest rivers and with unusually consistent year-round flow. Riparian strips contain some of the most extensive gallery (rainforest) vegetation in the Northern Territory. In addition, the catchment is a high priority for development, having been identified as one of the only parts of the Northern Territory suitable for rain-fed crops (based on climate) and with potential for extensive irrigation, based on soil characteristics and both surface and subsurface hydrology (Pascoe-Bell et al. 2011). There is a clear need to jointly identify priorities for development and conservation, and to resolve conflicts between them.

Fig. 1. Daly catchment property boundaries and land use as defined by ABARES land-use mapping. Inset shows the Northern Territory (white) and the Daly catchment (black).

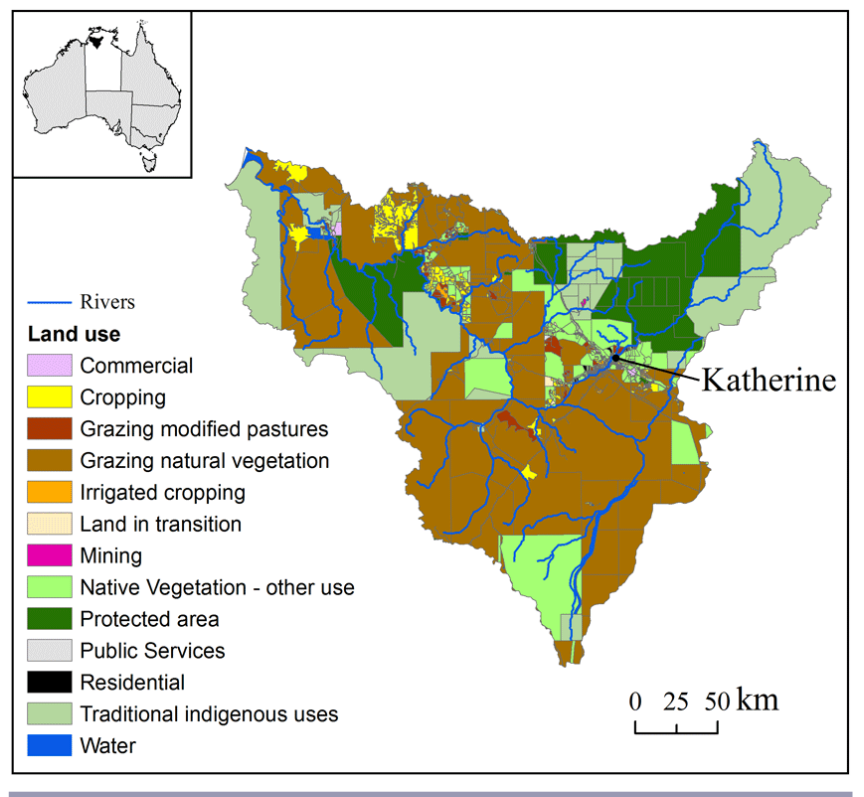

In 2011 the Daly River Management Advisory Committee (DRMAC) commissioned our involvement as independent researchers to undertake an integrated conservation and development planning process. DRMAC was created in 2006 to work with relevant government agencies to advise on sustainable resource use and conservation in the Daly catchment. DRMAC promotes high standards of management of land and water and advises the relevant minister. The design of the Daly clearing guidelines (NRETAS 2010) and water allocation plans relied on direct involvement by DRMAC. DRMAC is composed of a chair and 12 members representing all major stakeholders in the catchment, except the mining and energy sectors. Included are three indigenous landowner representatives selected by the Aboriginal Reference Group (ARG) that comprises 12 language groups. DRMAC's representative structure supports collaborative decision-making processes with strong ties to research providers, decision makers such as ministers, and members of local communities (Dale et al. 2014).

We designed the planning and engagement process (Fig. 2) in collaboration with DRMAC. The agreed-upon planning timeline was three years (2012-2014) with the focus of the first year being objective-setting with DRMAC and associated data collection and synthesis. Later focal areas were identified as engagement 
(year 2) and production of land-use scenarios and follow-up engagement to identify a preferred final land-use scenario (year 3). The results of this study focus mainly on the engagement process and its outcomes. The three-year planning process broadly follows the 11-stage process of systematic conservation planning outlined by Pressey and Bottrill (2009).

Fig. 2. The planning and engagement process for the Daly River catchment, designed in collaboration with the Daly River Management Advisory Committee (DRMAC). (a) The planning process broadly followed the 11-stage systematic conservation planning process outlined by Pressey and Bottrill (2009). The stages are represented here in a circular fashion because DRMAC focuses on an adaptive management approach and, realistically, any regional plan is subject to refinements and adjustments (Pressey et al. 2013), especially during implementation and monitoring. (b) The process of stakeholder engagement was designed to focus on the stages from objective setting to systematic planning and assessment (rectangle in part a). Stages with stars indicate recognition of feedback from stakeholders. The engagement process includes: (1) DRMAC objective-setting sessions; (2) Elicitation of resident well-being factors (this stage, described in the Methods, involved two open forums to raise awareness of the planning process and purpose of engagement, five stakeholder focus groups to inform survey design and content, followed by a mail survey to catchment residents and then integration of well-being factors into the plan's objectives, as indicated by the first star); (3) Designing future land-use scenarios based on plan objectives; (4) Integration of future scenarios and wellbeing preferences and satisfaction ratings for catchment changes to assess potential impacts of scenarios on social, economic, and environmental aspects of life in the catchment, indicated by second star; and (5) Presentation of scenarios to stakeholder groups to further refine objectives and identify a final land-use scenario for the development and conservation plan, indicated by third star.

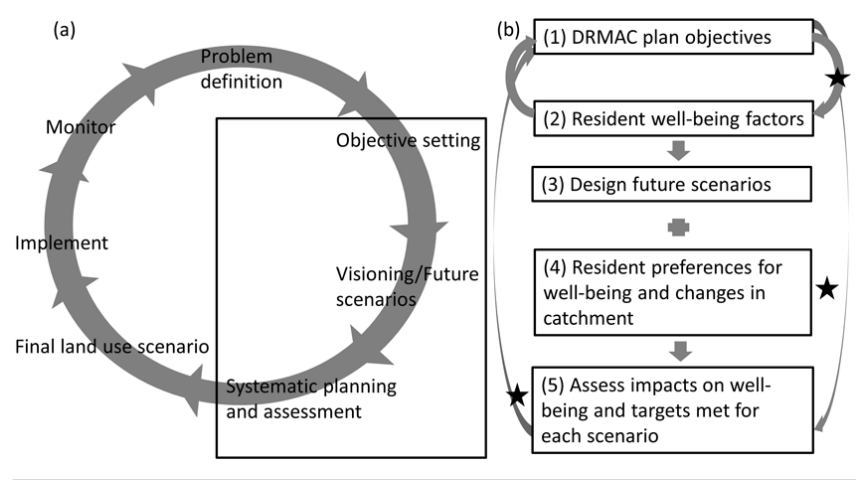

Planning for the Daly catchment was initiated with a feedback session with DRMAC in which a clear problem statement was drafted and the solution was to design a strategic plan for development and conservation in the catchment. The next step was to set explicit objectives for the plan. We undertook a series of objective-setting sessions with DRMAC to first identify qualitative goals for conservation and development and their associated actions (Table 1). Based on these goals, we compiled all available data on relevant spatially discrete features from government and scientific experts. These data sets were then presented to DRMAC and a final session identified quantitative spatial objectives based on qualitative goals and spatial data (see Pressey and Bottrill 2009 regarding the generic nature of this process in conservation planning). The objectives reflected existing policy, such as government protection targets to meet Convention on Biological Diversity commitments (CBD 2010), relevant legislation, and plans that inform land uses, e.g., clearing guidelines (NRETAS 2010), or the expressed views of experts and other stakeholders (Table 1). These objectives will be an integral component of spatial planning for the catchment, influencing the selection of areas for development and conservation with planning software (Ball et al. 2009, Watts et al. 2009).

With spatial objectives in place, the next stages of the planning process will develop and test different land-use scenarios before selecting a final scenario for the plan. Land-use scenarios will be designed using Marxan with zones (Watts et al. 2009) to optimally plan for multiple land uses while meeting objectives. The land-use scenarios will be coupled with water-use profiles for agricultural land and assessed using an existing tool for evaluation of management scenarios developed for the Daly (Pantus et al. 2011). The final plan will involve the land-use scenario, or a variation thereof, which meets the stated objectives and is best aligned with stakeholders' preferences. Selection of the final landuse scenario and implementation of the plan was to be guided by DRMAC through adaptive planning, including refinement of objectives, updating of the plan, and evaluation of ongoing resource-use decisions. However, in 2013, the government chose to discontinue support of DRMAC. We have therefore proceeded with the final phase of planning by shifting our feedback from DRMAC to the government and relevant stakeholders, those who were members of DRMAC as well as the broader public within the catchment. Implementation of the plan is uncertain but the plan's outcomes will be provided to both appropriate NT Government departments and a newly formed Territory-wide catchment advisory committee (NTCAC).

\section{Strategy for stakeholder engagement}

DRMAC requested a broad process of community engagement, in addition to engagement with key representatives of stakeholders. DRMAC, as the commissioning body for the plan, agreed to manage the process of setting objectives, but wanted to ensure that the objectives reflected people's ties to and expectations about the catchment. An engagement strategy was therefore designed to include community forums, focus groups, and a survey sent to all residents of the catchment (Fig. 2b), with scope for feedback from stakeholders to refine objectives and direct subsequent stages of planning. DRMAC requested that the engagement process focus on eliciting the preferences of catchment residents. This reflected DRMAC's catchment-specific role, as well as the availability of previous research that has identified broader regional and national perspectives on values associated with the Daly catchment (e.g., Zander et al. 2010, 2013, Zander and Straton 2010, Larson et al. 2013).

Engagement was initiated with presentations at community forums and media regarding the planning process to increase awareness and to receive initial community responses to the plan's purpose of reconciling future development and conservation. A 
Table 1. Qualitative goals related to well-being identified through the objective-setting process with the Daly River Management Advisory Committee (DRMAC). Each broad qualitative goal was mapped to one or more of the four well-being domains that focus groups identified. Under each goal, the associated actions, available mapped features, and spatial, quantitative objectives are listed. N/ $\mathrm{A}$ indicates that there were no available map products.

\begin{tabular}{|c|c|c|}
\hline Qualitative goals and related actions & Spatially discrete features & Quantitative objectives \\
\hline \multicolumn{3}{|l|}{ Maintain water quality in rivers (Biodiversity) } \\
\hline Manage soil erosion & N/A & $\begin{array}{l}\text { None defined, but performance of land-use } \\
\text { scenarios will be assessed quantitatively in } \\
\text { relation to soil-erosion levels with existing } \\
\text { water-management tool (Pantus et al. 2011) }\end{array}$ \\
\hline Manage pollutants & N/A & $\begin{array}{l}\text { None defined, but performance of land-use } \\
\text { scenarios will be assessed quantitatively in } \\
\text { relation to pollutant levels with existing } \\
\text { water-management tool (Pantus et al. 2011) }\end{array}$ \\
\hline \multicolumn{3}{|l|}{ Maintain water flow of rivers (Biodiversity) } \\
\hline Manage water extraction & N/A & $\begin{array}{l}\text { None defined, but performance of land-use } \\
\text { scenarios will be assessed quantitatively in } \\
\text { relation to water-extraction levels with } \\
\text { existing water-management tool and } \\
\text { reflecting existing water plan and associated } \\
\text { extraction limits (Pantus et al. 2011) }\end{array}$ \\
\hline \multicolumn{3}{|c|}{ Maintain fish populations (Biodiversity and Recreational) } \\
\hline Manage water extraction & N/A & $\begin{array}{l}\text { None defined, but performance of land-use } \\
\text { scenarios will be assessed quantitatively in } \\
\text { relation to water-extraction levels with } \\
\text { existing water-management tool and } \\
\text { reflecting existing water plan and associated } \\
\text { extraction limits (Pantus et al. 2011) }\end{array}$ \\
\hline Protect important stream reaches & Fish species habitat mapping & $\begin{array}{l}17 \% \text { of habitat for each species (reflecting } \\
\text { Convention on Biological Diversity targets; } \\
\text { CBD 2010) }\end{array}$ \\
\hline \multicolumn{3}{|l|}{ Protect biodiversity (Biodiversity) } \\
\hline Protects sites of conservation significance & $\begin{array}{l}\text { Sites of conservation significance }{ }^{\dagger} \text { (NRETAS } \\
\text { 2009) }\end{array}$ & $\begin{array}{l}100 \% \text { of sites (reflecting expert opinion on } \\
\text { value of sites) }\end{array}$ \\
\hline $\begin{array}{l}\text { Protect representative portions of species' } \\
\text { habitats }\end{array}$ & $\begin{array}{l}\text { Vegetation mapping and bioregion } \\
\text { boundaries }\end{array}$ & $\begin{array}{l}17 \% \text { of extent of each vegetation type and } \\
\text { bioregion (reflecting CBD targets; CBD } \\
2010 \text { ) }\end{array}$ \\
\hline $\begin{array}{l}\text { Protect representative portions of species' } \\
\text { occurrences }\end{array}$ & $\begin{array}{l}\text { Predicted occurrences of fish, bird, and turtle } \\
\text { species }\end{array}$ & $17 \%$ of occurrences (reflecting CBD targets) \\
\hline Protect wetlands & Mapped wetlands & $\begin{array}{l}100 \% \text { of wetlands (reflecting expert opinion } \\
\text { on value of sites) }\end{array}$ \\
\hline Protect rainforest galleries & Mapped rainforest & $\begin{array}{l}100 \% \text { of rainforests (reflecting expert opinion } \\
\text { on value of sites) }\end{array}$ \\
\hline Manage fire threats to biodiversity & Expected savanna burning abatement ${ }^{\star}$ & $\begin{array}{l}10 \% \text { of abatement (measured in metric tonne } \\
\text { of carbon dioxide equivalents; Adams and } \\
\text { Setterfield 2013); constrained to indigenous } \\
\text { land, which is the primary tenure engaged in } \\
\text { abatement activities and the associated offset } \\
\text { market. }\end{array}$ \\
\hline \multicolumn{3}{|c|}{ Increased development and diversification of land uses and industries (Commercial) } \\
\hline Clear suitable land for agricultural use & Land suitability categories & $\begin{array}{l}100 \% \text { of highly suitable land cleared with a } \\
\text { maximum of } 20 \% \text { of catchment area cleared } \\
\text { (reflecting clearing guidelines; NRETAS } \\
\text { 2010) }\end{array}$ \\
\hline Savanna burning (carbon offsets) & Expected savanna burning abatement ${ }^{*}$ & $\begin{array}{l}10 \% \text { of abatement (measured in metric tonne } \\
\text { of carbon dioxide equivalents; Adams and } \\
\text { Setterfield 2013); constrained to indigenous } \\
\text { land, which is the primary tenure engaged in } \\
\text { abatement activities and the associated offset } \\
\text { market. }\end{array}$ \\
\hline
\end{tabular}


Proper use of land and natural resources (Commercial)

Constrain land clearing to suitable land Land suitability categories

Develop new settlements and townships (Social-Cultural)

Invest in infrastructure, release land to develop

new settlements, and build critical mass in

existing communities

Maintain and protect indigenous cultural sites (Social-Cultural)

Protect identified indigenous cultural sites
No available data. This type of data is highly guarded and difficult to elicit. Although there are methods for data elicitation and management on cultural sites, it was determined that this goal was outside the scope of the planning process. Groups such as the Aboriginal Reference Group or the Aboriginal Areas Protection Authority are likely to play a role in protecting sites as landuse changes occur.

Maintain important social and cultural sites (Social-Cultural and Recreational) Protect important social-cultural sites and Inclusion of sites from survey data asking recreational spots respondents to report those they would like protected. These are not considered to be sensitive in terms of cultural values.
Allow clearing only on suitable land

Required infrastructure and associated costs assessed postplanning

None defined

$100 \%$ of consensus sites

\footnotetext{
${ }^{\dagger}$ The Northern Territory Government undertook an assessment of conservation and heritage values and identified 67 of the most important sites for biodiversity conservation across the Territory, some of which are in the Daly catchment. By definition, these sites need adequate protective management.

"Savanna burning is an approved methodology for greenhouse-gas abatement under the Carbon Farming Initiative (CFI) in Australia (DCCEE 2011). It involves fire management to reduce the extent and timing of fires, by burning earlier in the dry season, and so reduce the total emissions associated with annual fires. Current enrolled properties for savanna-burning credits under the CFI are all indigenous.
}

survey was designed to elicit stakeholder preferences for different well-being factors and their satisfaction with potential changes in the catchment associated with both development and conservation. To inform the design of the survey, five focus groups were arranged. The survey results reported here will be used for three primary purposes: refining plan objectives, designing landuse scenarios, and targeting future engagement with stakeholder groups that have different preferences and could therefore play an integral role in building consensus around a final land-use scenario. In addition, there will be targeted engagement with groups that were not well sampled in the initial process described here. Because DRMAC was the original commissioner and planned implementer of the plan, the focus on resident preferences was consistent with the governing body's priorities and broader responsibilities. However, given the change in DRMAC's status and shift in the plan implementation strategy, there could be a disconnect between resident preferences and the broader Northern Territory Government policy for the catchment. One way of navigating the potential disconnect in resident preferences and government policy is to explicitly include relevant government departments in future engagement processes to help build consensus around a final land-use scenario both at a local resident level and at a broader territory level.

\section{Focus groups and survey design}

We chose the conceptual framework of human well-being to elicit a subjective quantification of the factors influencing well-being that were most important to respondents living in the Daly catchment. We chose human well-being as the framework because it comprises basic human needs, economic needs, environmental needs, and subjective happiness (Costanza et al. 2007, Summers et al. 2012) and is therefore well suited for understanding how broad land-use changes, such as clearing for intensive agriculture or increasing nature reserves, might result in changes across these components. Furthermore, there is a substantive body of literature on subjective well-being and overall life satisfaction as an alternative way of looking at the "value" of the environment (Kristoffersen 2010) and there is widespread consensus that selfreported measures of life satisfaction are valid, replicable, and reliable (Diener 2009). Furthermore, we also wanted to identify priority areas for policy makers. Therefore, we selected the approach developed by Larson (2010) that first seeks to identify factors that individuals feel are important to their overall wellbeing, by asking them (thus a bottom-up, rather than top-down approach). It then asks people to indicate how important each of those factors are using a quantitative scale, and how satisfied they are with each factor. Finally, it calculates a composite metric of importance and satisfaction for identifying priorities.

Previous studies have demonstrated that well-being factors are context-dependent (Millennium Ecosystem Assessment 2005), so factors important to local respondents should be elicited specifically for the region or ecosystem in question (e.g., Marans 2003, Larson 2009). We therefore ran a series of five focus groups at various locations in the catchment to ensure that a range of stakeholders, based both on location and industry, were present. The size of focus groups ranged from 5 to 20 participants. The primary purpose of the focus-groups was to identify a list of wellbeing factors specific to life satisfaction for residents in the Daly catchment. At larger focus groups we asked attendees to split themselves into groups of about five people. Groups were then asked to list the things that were most important to them in their lives in the Daly. As they began to list items, they were given the further prompt of, "What contributes most to your happiness? 
Table 2. Final list of well-being factors and associated broad domains used in the survey.

\begin{tabular}{ll}
\hline \hline Statements about well-being factors & Domain \\
\hline 1. The river provides habitat for iconic species (like barramundi, black bream, long-neck turtles, sawfish) & Biodiversity \\
2. The catchment provides habitat for a variety of plants and animals & Biodiversity \\
3. A place where the river flows naturally and there are no dams & Biodiversity \\
4. A place for natural heritage (e.g., important National Parks and unique environments) & Biodiversity \\
5. A place for development and intensified production & Commercial \\
6. The tourism industry in the catchment provides jobs and income & Commercial \\
7. The agricultural industry in the catchment provides jobs and income & Commercial \\
8. The mining industry in the catchment provides jobs and income & Commercial \\
9. The cattle industry in the catchment provides jobs and income & Commercial \\
10. The forestry industry in the catchment provides jobs and income & Commercial \\
11. A place that is relatively free from congestion and major development & Social-Cultural \\
12. A place that supports families and communities & Social-Cultural \\
13. A place to preserve traditional (e.g. Indigenous) cultural values & Social-Cultural \\
14. A place for research, teaching, and learning & Social-Cultural \\
15. It is important to keep the area in good condition for future generations & Social-Cultural \\
16. Even if I could never visit ANY part of the Daly, I would still like to know "it is there" & Social-Cultural \\
17. Fishing and hunting for fun & Recreational \\
18. Swimming, camping, boating, being in country & Recreational \\
19. Fishing and hunting for fresh food & Recreational \\
\hline
\end{tabular}

Things you like to do, places you like to visit, how you get by?" A person from each group summarized key points from the discussion and the lists were placed on walls around the room. Each participant was then given five "votes" (stickers) to be allocated across the items they thought were most important to assess. They could place all stickers on one item or distribute them across separate items. We then compiled the list of items and asked participants to assign them to broad domains: biodiversity, commercial, social-cultural, and recreational. Participants were then given a break and the list of items that received "votes" was organized by domain and placed on display. Participants were then asked to provide feedback on whether they felt the list of items was incomplete. They were also asked to engage in a group discussion about any concerns they had about their lives in the catchment at the time or about any potential changes to their lives in the catchment in the future.

A final list of well-being factors was compiled based on the five focus groups and structured to comprehensively include the toppriority items (those with "votes") identified by the groups. This list was then circulated to focus-group attendees who had agreed to give further feedback and also to relevant representatives of government agencies and communities. These individuals were asked to provide feedback on the completeness of the list. The engagement process to this point provided a basis for designing the survey.

The survey was designed to elicit four types of data: (1) frequency of recreational activities in the catchment and any areas of importance for recreation or protection, (2) well-being importance and satisfaction, (3) satisfaction with hypothetical changes to land uses in the catchment, and (4) socio-demographic background. The final well-being factors included in the survey contained 19 factors grouped into four domains based on information from the focus groups. Table 2 lists the well-being factors presented in the survey. In case this list was not representative of all aspects of well-being, we included the option for survey respondents to list additional items; however, only six respondents took advantage of this option, indicating that our list was reasonably comprehensive.

We selected a scale of $0-10$ for respondents to rate both the importance of and satisfaction with the current state of each wellbeing factor, with 0 being not at all important/completely dissatisfied and 10 being very important/completely satisfied (for a discussion on methodological issues and appropriates of Likert scale measure see Cummins 2003). The list of hypothetical changes identified from the group discussions, about which residents in the catchment were concerned, included: (1) characteristics of life in the catchment such as the level of community support and infrastructure; (2) changes in industry and associated land uses in the catchment; and (3) environmental changes such as the level of water in the Daly River (currently no dams and relatively little extraction), amount of clearing of native vegetation, and overall health of native plants and animals. In addition, the issue of land clearing was a topic raised consistently in focus groups. We therefore included two separate questions in the survey relating to hypothetical changes in the catchment. The first was a list of hypothetical changes relating to life in the catchment (community, social aspects, industry, and environment) and the second was about incremental increases in clearing (from $10-100 \%$ ). Respondents were asked to provide their level of satisfaction for each change, from 10 to $100 \%$ in $10 \%$ increments, using a 9-point Likert scale. Current property clearing within the catchment ranges widely from very small percentages up to nearly complete clearing. In addition, focus groups revealed variability in participants' responses to acceptable levels of clearing both at the property and catchment scales. To enable us to distinguish preferences for incremental clearing, we therefore used a finely graded Likert scale coupled with small clearing increments across the full range of potential clearing.

\section{Data collection and analyses}

We sent the survey by mail to all available household addresses in the catchment (see Appendix 1 for full survey). We used the Dillman tailored design method (Dillman 2007) with the original 
Table 3. Characteristics of respondents and of residents in the Daly River catchment (catchment resident statistics derived from Australian Beareau of Statistics census data summarized at the catchment level, Larson and Alexandridis 2009).

\begin{tabular}{lcc}
\hline \hline & Catchment & Respondents \\
\hline Median family weekly income & 900 & 1680 \\
Average age & 33 & 53 \\
Average household size & 2.9 & 3.03 \\
Aboriginal people (\% of population) & $27.60 \%$ & $23.44 \%$ \\
Torres Strait Island People (\% of population) & $0.40 \%$ & $0.00 \%$ \\
Women with less than three children & $65.00 \%$ & $71.70 \%$ \\
> years school & $65.00 \%$ & $90.58 \%$ \\
Employed in government services sector & $35.00 \%$ & $40.11 \%$ \\
Employed in retail sector & $5.00 \%$ & $2.14 \%$ \\
Employed in mining sector & $1.00 \%$ & $1.07 \%$ \\
Employed in construction sector & $8.00 \%$ & $5.88 \%$ \\
Employed in agricultural, forestry, and fisheries sector & $6.00 \%$ & $10.70 \%$ \\
\hline
\end{tabular}

survey sent in May 2013 and replacement surveys sent two and five months later. Of the 2387 addresses contacted, 20 requested to be removed from the survey and 767 addresses were no longer active, leaving a total of 1600 possible respondents. The questionnaires were supplemented by 26 surveys completed through one-on-one interviews specifically targeting indigenous residents who typically have low response rates in mail-out surveys (Larson et al. 2013). The response rate to the survey (about 13\%, or 209 of 1600 households) was slightly less than that of similar surveys in the region (16-25\% response rate for region reported; Zander et al. 2010, Adams et al. 2012, Larson et al. 2013). The low response rate was probably attributable to survey fatigue, with a large number of academic, rural, and census surveys having been conducted in this region in recent years. Although the low response rate means that our results are not considered representative of the entire catchment population, we did find important differences in preferences between stakeholder groups that do not rely on an assumption of "representativeness" to usefully guide further engagement and inform plan objectives. Of the responses received, equal numbers were from males and females and respondents were representative of characteristics of catchment households and employment sectors (Table 3). Respondents were not, however, representative of income, education, or age, parameters for which were all above those for the catchment generally (Table 3 ), but in line with other survey responses from the region (Larson et al. 2013).

We analyzed the survey data in several ways. We calculated the mean importance scores for the 19 well-being factors and confidence intervals around the means. We tested for differences in reported preferences for well-being factors between different stakeholders based on reported socio-demographic characteristics. To do this, we developed explanatory linear regression models of responses for each well-being factor in relation to possible influencing factors, using forward and backward removal to select the best subset of predictors for each model. The best-fit model was selected using Akaike's information criterion (AIC). We explored both linear regression and ordered logistic regression and found both gave almost identical results. We therefore report the linear regression models. Based on the 19 regressions, we identified two key stakeholder groups that were associated with different factors: indigenous respondents and respondents who earn an income from agriculture (livestock and crops aggregated to reflect sector statistics for catchment). We therefore explored the stated preferences for these two groups by comparing their average importance scores and confidence intervals at the broad domain level (averaged responses across statements for each domain). To identify potential priorities for management and policy, we used a method developed by Larson (2010) in which a composite index, the Index of Dissatisfaction, is used to identify policy priorities based on either high importance or high dissatisfaction. The Index of Dissatisfaction for well-being factor $k(I D S$,$) is calculated as:$

$$
I D S_{k}=I * D * \frac{n_{k}}{N}
$$

where $I$ is importance, $D$ is dissatisfaction (the inverse of satisfaction $S$ calculated as $10-S$ ), $n_{k}$ is the number of respondents who reported both satisfaction and importance scores for wellbeing factor $k$, and $N$ is the total number of respondents. Last, we calculated the mean reported satisfaction (reported on a 9point Likert scale) for hypothetical changes in the catchment.

\section{RESULTS}

The highest ranked well-being factors were in the socio-cultural and biodiversity domains (Fig. 3). The well-being factor "It is important to keep the area in good condition for future generations" had the highest mean importance and smallest confidence interval, indicating strong concurrence among respondents about the importance of maintaining the condition of the Daly catchment. Commercial factors were ranked least important and the confidence intervals for commercial factors did not overlap with the top-ranked well-being factors in the biodiversity and socio-cultural domains (Fig. 3).

Our explanatory models of the relationships between the reported importance values and socio-demographic characteristics of respondents highlighted several types of stakeholders often associated with each of the well-being factors (Table 4). For example, indigenous respondents and respondents employed in the government and agricultural sectors were included in many of the best-fit models. Notably, indigenous respondents and those employed in the government sector had negative relationships with commercial factors while respondents employed in the agricultural sector had positive relationships with these factors (Table 4). The low explanatory power of the regressions (adjusted 
Table 4. Characteristics of respondents $(n=141)$ determining the importance of the 19 factors tested. Characteristics included in the best explanatory model of importance factors for each factor are displayed by plus or minus, indicating that the variable had a positive or negative relationship, respectively, with the perceived importance of the factor.

\begin{tabular}{|c|c|c|c|c|c|c|c|c|c|c|c|c|c|c|c|c|c|c|c|}
\hline & 1 & 2 & 3 & 4 & 5 & 6 & 7 & 8 & 9 & 10 & 11 & 12 & 13 & 14 & 15 & 16 & 17 & 18 & 19 \\
\hline Male & & & & & & + & + & & & & & & & & & - & & & \\
\hline Has Children & & & + & + & & + & & & & & & & & & & & & + & \\
\hline Age & & & & & + & & & & & & - & & & & - & - & + & & \\
\hline Indigenous & + & + & & & - & - & - & & & - & & + & & + & + & + & + & + & + \\
\hline $\begin{array}{l}\text { Size Of } \\
\text { Household }\end{array}$ & & & & - & + & & + & & + & + & & & + & & & & + & & \\
\hline Catchment & & & & & & & + & & & + & + & & & & - & & & - & \\
\hline $\begin{array}{l}\text { Resident } \\
\text { Self } \\
\text { Employed }\end{array}$ & - & & & & & & & & & & & & & & & & & & \\
\hline $\begin{array}{l}\text { Employed } \\
\text { Government }\end{array}$ & - & & & & & & - & & - & - & - & & & + & + & + & & & \\
\hline $\begin{array}{l}\text { Agricultural } \\
\text { Industry }\end{array}$ & & & & & + & - & - & + & - & & & & & & + & & + & & \\
\hline $\begin{array}{l}\text { Passive } \\
\text { Income }\end{array}$ & - & - & & & & + & & & - & & & & & + & & + & & & \\
\hline Income & & & & - & & & + & & + & & & & & & & & & & \\
\hline Adjusted $\mathrm{R}^{2}$ & 0.098 & 0.093 & 0.020 & 0.076 & 0.072 & 0.115 & 0.122 & 0.021 & 0.083 & 0.077 & 0.041 & 0.027 & 0.047 & 0.068 & 0.087 & 0.172 & 0.153 & 0.082 & 0.118 \\
\hline
\end{tabular}

Fig. 3. Mean importance values and confidence intervals for 19 well-being factors. Color of bar indicates the domain: biodiversity (green), commercial (purple), social-cultural (blue), recreational (orange).

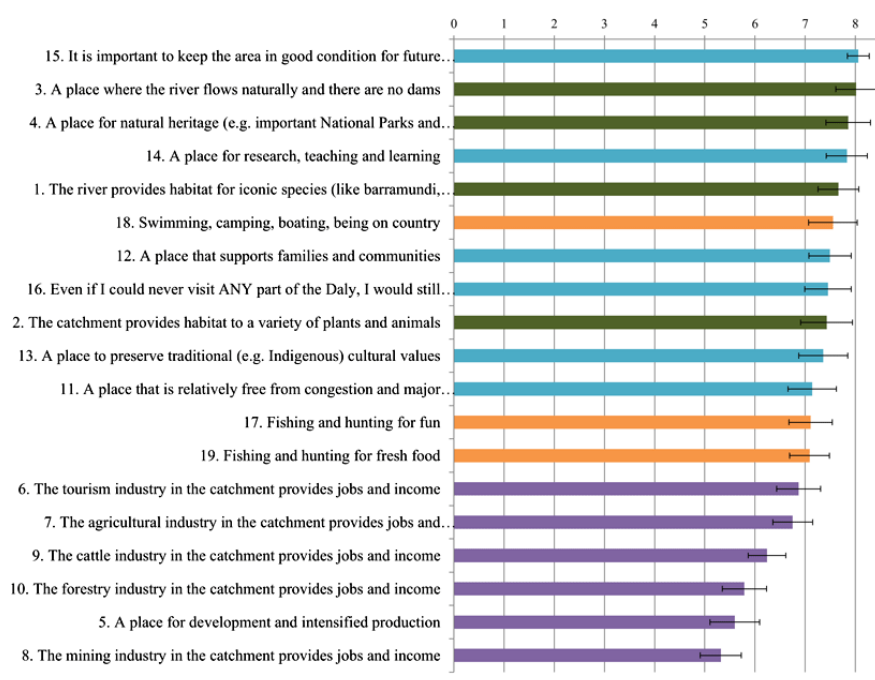

$\mathrm{R}^{2}$ range from 0.02 to 0.172 ) was not a major concern, given the exploratory nature of these analyses and the lower importance of explanatory power compared to establishing that particular stakeholder groups differed in their associations with well-being factors.

Differences in well-being preferences between the agricultural sector and indigenous respondents were highlighted by the importance values given by these groups to factors grouped in domains (Fig. 4). The confidence intervals for indigenous respondents and those who reported earning an income from agriculture did not overlap
Fig. 4. Average importance values given to well-being factors, by domain, for three groups of respondents: those earning an income from agriculture, indigenous respondents, and total respondents. Confidence intervals for three of the four domains (circled) do not overlap between indigenous respondents and those who earn an income from agriculture.

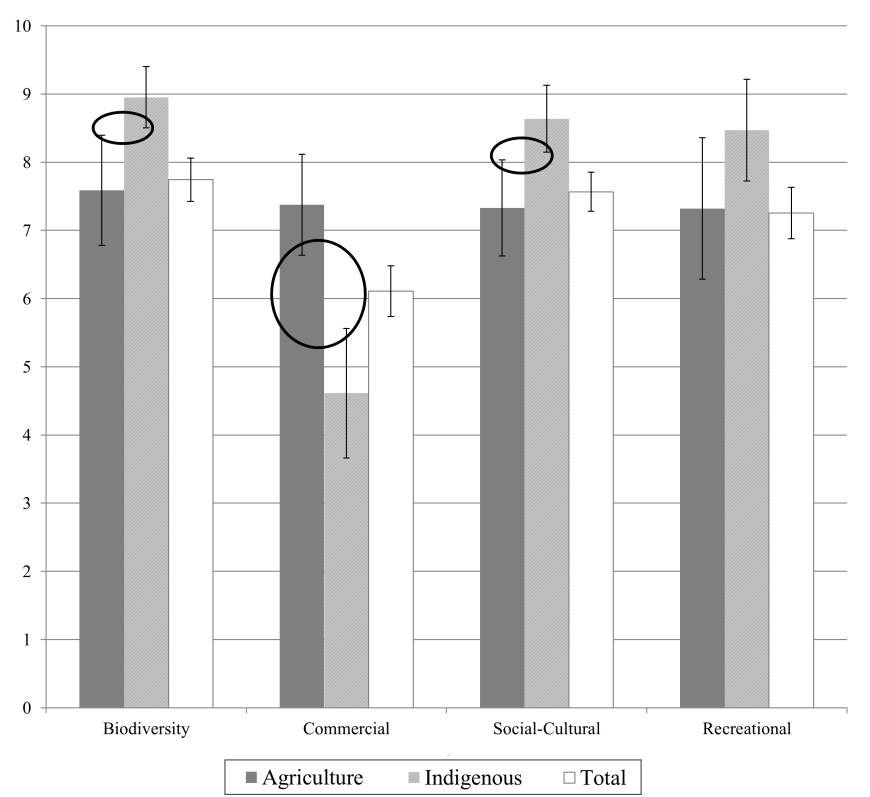

for three of the four domains (biodiversity, commercial, sociocultural), with indigenous respondents placing greater importance on biodiversity and socio-cultural factors and agricultural respondents placing greater importance on commercial factors. 
The factors with the highest Index of Dissatisfaction scores were in the commercial domain, and the dominant reason for highest scores was low reported satisfaction (Table 5). For these factors, respondents noted concerns over environmental impacts from existing developments. They also noted concerns over sustainability of future development and lack of science to inform assessment of impacts as well as a lack of transparent decision making and regulations on industry from government. Respondents also stated concerns over the economic viability of certain industries, in particular the low level of tourism and lasting negative impacts of the live-trade ban on the cattle industry. Recreational factors (well-being factors 17, 18) also had reasonably high IDS scores because of relatively high importance and moderate dissatisfaction, with the primary concern being observed changes in fish abundance. Factors associated with the other two domains (biodiversity, socio-cultural) all had similar satisfaction ratings. Most concerns associated with these factors echoed the already-discussed concerns of observed environmental degradation and lack of transparent decision making.

When asked about potential changes in aspects of daily life in the catchment, respondents reported that they would be strongly dissatisfied with an increase in the cost of living and a reduction in recreation spots but would be strongly satisfied with an increase in infrastructure (Fig. 5). Responses to changes in economics resulted in divergent responses from indigenous respondents and those employed in the agricultural sector, consistent with importance results (Fig. 4). For example, relative to total respondents, indigenous respondents would be more dissatisfied and agricultural respondents more satisfied with an increase in agriculture (mean satisfaction of 2.95 and 6.04, respectively, with nonoverlapping confidence intervals, Fig. 5). Responses to five environmental changes also differed significantly between indigenous and agricultural respondents (Fig. 5).

Across all respondents, satisfaction was greatest for levels of increased clearing of 10 or $20 \%$, but then declined steadily with larger percentages (Fig. 6). However, even for the lowest percentage clearing value $(10 \%)$, the average satisfaction response was 4.5 reflecting that respondents would be slightly less satisfied with this change. The current clearing across the Daly catchment is approximately $5.5 \%$, so this could reflect a preference for no change to the existing clearing level. In contrast, agricultural respondents were neutral (confidence interval around reported satisfaction includes a value of 5) to clearing up to $30 \%$. Differences in responses to environmental changes between agricultural and indigenous respondents (Fig. 5) were also reflected in responses to levels of future clearing. For increases between 20 and $60 \%$, agricultural respondents were more satisfied than indigenous respondents.

\section{DISCUSSION}

Our study illustrates one method of eliciting stakeholder preferences for well-being factors that can be used to inform landuse objectives and relevant indicators for changes in residents' satisfaction with present and possible future conditions in a region. We chose a well-being framework to elicit stakeholder preferences because we can use the elicited data to refine plan objectives that will be used in the design of land-use scenarios. We can also use these data as indicators when testing the impacts of alternative land-use scenarios. Our approach provided a
Fig. 5. Mean satisfaction ( 0 being much more dissatisfied and 9 being much more satisfied) and confidence intervals for hypothetical changes in the catchment for three groups of respondents: those who earn income from agriculture, indigenous respondents, and total respondents. Changes to daily life (blue) covered cost of living, infrastructure, recreation spots, and population. Economic changes (purple) concerned changes in agriculture, tourism, and mining. Environmental changes (green) were a dam on the Daly, reduction in dryseason water level in the Daly, abundance of trees, and abundance of fish. Agricultural respondents are shown by solid color, indigenous respondents with diagonal hatching, and total respondents with white bars. Significant differences between agricultural and indigenous respondents are circled.

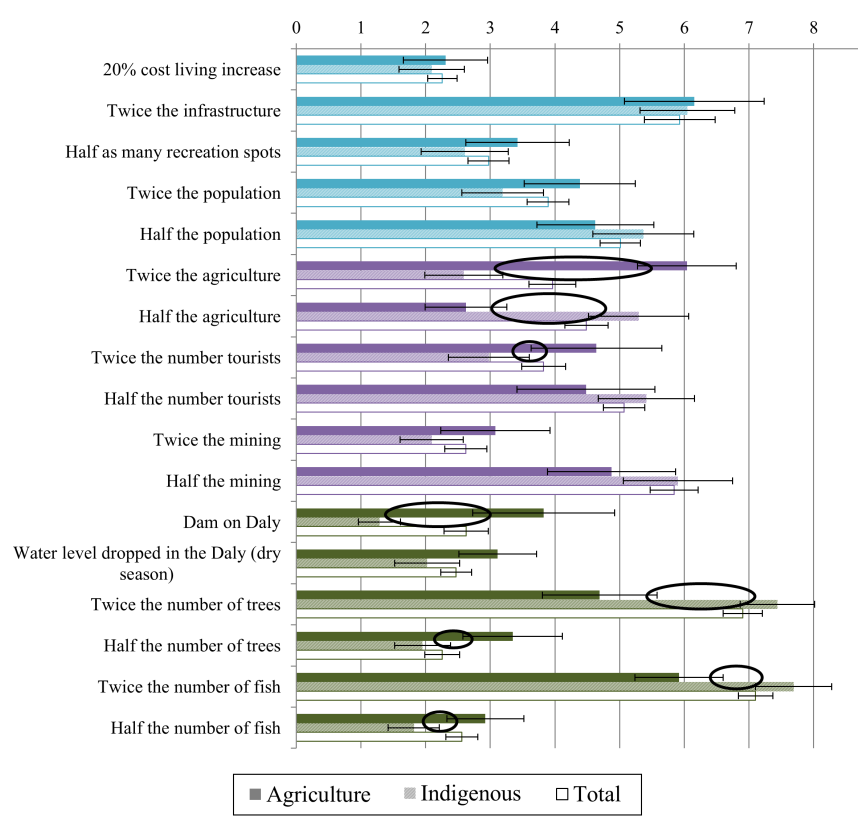

structured elicitation process for engaging representatives of a region's population in objective setting and plan design.

We identified 19 well-being factors that aligned with four broad well-being domains: biodiversity, commercial, socio-cultural, and recreational. By eliciting residents' preferences for these 19 factors, we were able to compare their relative importance across stakeholder groups. Our analysis suggests that, on average, catchment residents place low importance on commercial factors relative to other aspects of well-being (Fig. 2 and 3). This is consistent with findings regarding well-being factors related to water in the same region, indicating that socio-cultural factors were assigned highest importance (Larson et al. 2013, Zander et al. 2013). Our result is also consistent with feedback provided throughout the public engagement process in which residents regularly noted that they moved to the Daly region because of its environmental and social attributes.

Our analysis highlights both similarities and potential conflicts between DRMAC's objectives and residents' sense of well-being. DRMAC's objectives are mostly well aligned with stakeholder's 
Table 5. Index of Dissatisfaction (IDS) for well-being factors; higher values indicate greater importance, less satisfaction, and/or higher percentages of respondents providing information about the factor. The components of the IDS are provided for each factor: mean importance (I), mean satisfaction (S), and percentage of respondents who provided information about both parameters (\%). Mean importance reported here might not exactly match values provided in Figure 3 because only those respondents who answered questions for both importance and satisfaction $(n=145)$ were included in values for IDS. Reasons for dissatisfaction reported in the survey are given for each factor.

\begin{tabular}{lccccl}
\hline \hline & $\mathrm{I}$ & $\mathrm{S}$ & $\%$ & $\mathrm{IDS}$ & Reasons for dissatisfaction (concerns) \\
\hline $\begin{array}{l}\text { 7. The agricultural industry in the catchment } \\
\text { provides jobs and income }\end{array}$ & 6.47 & 5.99 & $93.79 \%$ & 24.37 & $\begin{array}{l}\text { Environmental impacts (pollution and water } \\
\text { extraction) }\end{array}$ \\
$\begin{array}{l}\text { 6. The tourism industry in the catchment } \\
\text { provides jobs and income }\end{array}$ & 6.69 & 6.15 & $94.48 \%$ & 24.32 & $\begin{array}{l}\text { More tourism needed } \\
\text { Need for greater restrictions on where tourists can go } \\
\text { 9. The cattle industry in the catchment } \\
\text { provides jobs and income }\end{array}$ \\
& 5.88 & 5.69 & $93.79 \%$ & 23.74 & $\begin{array}{l}\text { Environmental sustainability } \\
\text { Need for greater restrictions on cattle access to } \\
\text { wetlands and river } \\
\text { Impacts of live-trade ban on economic sustainability }\end{array}$
\end{tabular}

10. The forestry industry in the catchment provides jobs and income

\section{A place for development and intensified production}

17. Fishing and hunting for fun

18. Swimming, camping, boating, being in country

8 . The mining industry in the catchment provides jobs and income

12. A place that supports families and communities

4. A place for natural heritage (e.g.,
important national parks and unique
environments)
15. It is important to keep the area in good
condition for future generations
14. A place for research, teaching, and
learning
11. A place that is relatively free from
congestion and major development
13. A place to preserve traditional (e.g.,
indigenous) cultural values
2. The catchment provides habitat for a
variety of plants and animals
1. The river provides habitat for iconic species
(like barramundi, black bream, long-neck
turtles, sawfish)
3. A place where the river flows naturally and
there are no dams
16. Even if I could never visit ANY part of
the Daly, I would still like to know "it is
there"
19. Fishing and hunting for fresh food

$\begin{array}{llll}5.64 & 5.41 & 91.03 \% & 23.55 \\ 5.37 & 5.15 & 88.97 \% & 23.2 \\ & & & \\ 7.18 & 6.71 & 95.86 \% & 22.62 \\ & & & \\ 7.68 & 7.01 & 97.93 \% & 22.5 \\ 5.05 & 5.13 & 89.66 \% & 22.04\end{array}$

$\begin{array}{lll}7.57 & 6.94 \quad 93.10 \%\end{array}$

8.06

8.17

7.99

7.10

7.42

7.69

7.89

7.98

7.69

7.48

7.26 Impacts of live-trade ban on economic sustainability and associated impacts on families and communities Concern over proper use of land and water Environmental impacts of forestry (erosion, weeds, water extraction)

Lack of transparent decision making from government (short-term plans serving vested interests instead of sound long-term economic development) Decreased fish numbers

Need for greater restrictions on boats and fishing access

Pollution

Lack of disclosure and transparency from companies Need for greater restrictions from government History of spills and inadequate clean-up Permanent negative environmental impacts Loss of community services (like clinics, sports clubs, facilities)

Not enough jobs

Cost of living too high (shops have insufficient selection and prices very high)

Population turnover (people come and go)

21.24

$90.34 \%$

$95.86 \%$

18.16

of increased water extraction and dams

Dam would change the river irrevocably

17.35 fire, water extraction, erosion)

Hard to get to country to practice culture 
Fig. 6. Mean satisfaction ( 0 being much more dissatisfied and 9 being much more satisfied) and confidence intervals for percentages of clearing in the catchment for three groups of respondents: those who earn an income from agriculture, indigenous respondents, and total respondents. Significant differences between agricultural and indigenous respondents are circled.

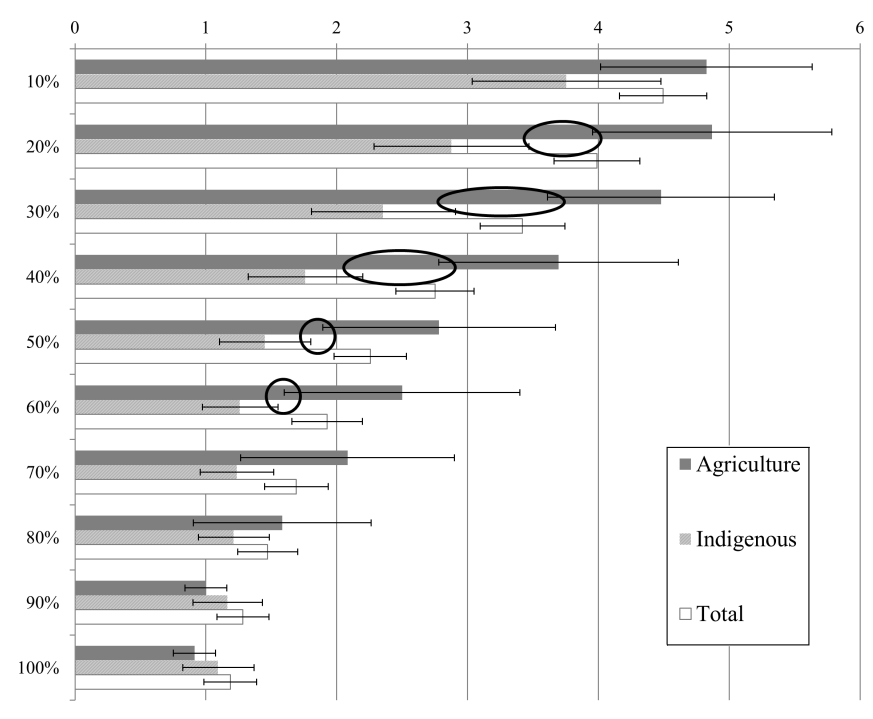

perceptions of well-being, in particular for biodiversity factors, maintaining fish populations (for both biodiversity and recreation), supporting communities through further investment in infrastructure, and planning of land use to ensure that land and water resources are used sustainably and appropriately.

A key goal for DRMAC is to plan for development; however, our analysis highlights that this goal could result in conflicts with residents' preferences. Development goals are well aligned with stakeholders who earn an income from agriculture, but could result in decreases in well-being of other, particularly indigenous, residents (Fig. 4). This accords with a previous study of the impacts of development, specifically concerning water-related values, demonstrating that these impacts would be greater for the indigenous population (Zander and Straton 2010, Jackson et al. 2012, Woodward et al. 2012, Stoeckl et al. 2013). This earlier work supports our own in highlighting likely trade-offs between stakeholder preferences for development in the catchment.

The Index of Dissatisfaction is one method for identifying issues that should be priorities for policy makers (Larson 2010). Based on Index of Dissatisfaction rankings, the top policy priorities for the Daly are associated with commercial factors (Table 5). Providing contextual detail to the index ranking, respondents listed concerns associated with both the current environmental impacts and future increased impacts associated with development. Respondents also stated desires for further restrictions on certain types of land uses and their impacts and more transparent decisions by policy makers. The importance of effective policy development surrounding future development and management of associated impacts is also highlighted by the respondents' satisfaction ratings for changes in the catchment. Respondents were on average dissatisfied with hypothetical increases in development (more agriculture, tourists, or mining) and associated environmental impacts (decrease in dry-season river-level, fewer fish, and fewer trees) (Fig. 5). Therefore, a rigorous analysis of how different levels of development will interact with biodiversity and recreational factors needs to be undertaken to ensure that a level of development is selected that balances these factors according to residents' preferences.

An important aspect of development in the catchment is the associated clearing of native vegetation. The stated actions and objectives associated with the development goals include clearing all suitable land within a limit of $20 \%$ of the catchment. The limit of $20 \%$ is based on clearing guidelines that DRMAC helped to develop. However, current government policy has indicated that these guidelines will not be implemented and the limit on total clearing is likely to be removed (Adams and Pressey 2014). The responses to hypothetical clearing in the catchment suggest that clearing more than $20 \%$ of the total catchment would result in increased dissatisfaction of residents. It is notable that the recommended clearing limit in the guidelines (guided by environmental principles) is similar to the level of clearing that residents would be willing to accept. Furthermore, a study including a sample of respondents from capital cities (Darwin and Sydney) found that people are prepared to pay substantial amounts to maintain the quality of the ecosystem services associated with the Daly River and less than half $(43 \%)$ of respondents considered 'Income from irrigated agriculture' when considering their preferences (Zander et al. 2013). Thus there is strong alignment of local, regional, and national preferences for the Daly. Furthermore, analyses show that this limit need not be restrictive for development and is thus consistent with territory policy for development in the north (Adams and Pressey 2014). Given this concurrence of environmental policy and public acceptability, the current government should reconsider enforcing the clearing limit of $20 \%$.

An associated aspect of clearing is how much water extraction is required to support different types and extents of intensive land uses. Given the high reported importance values associated with water (specifically well-being factors 1,3 , and 18) and reported concerns associated with recreational factors (decreased fish numbers), potential future impacts on water resources will need to be evaluated and communicated to residents, recognizing also the rarity of perennial rivers in northern Australia and the significance of the Daly's freshwater biodiversity (Kennard 2010).

Our analysis identified differences in preferences among key stakeholder groups that were consistent with previous work in the region (e.g., Zander et al. 2010, Zander and Straton 2010, Larson et al. 2013, Stoeckl et al. 2013). We found that the importance of well-being factors was markedly different between indigenous respondents and those who earn an income from agriculture. These two stakeholder groups represent a large proportion of both the catchment's overall population $(\sim 34 \%$; Table 3$)$ and its total area $(\sim 78 \%$ of which $\sim 26 \%$ is aboriginal land and $52 \%$ is private property and predominantly pastoral; Fig. 1; Adams et al. 2014). Given that these groups collectively control $78 \%$ of the catchment, they are likely to play a major role in building 
consensus around future decisions about development and conservation. Targeted engagement with these two groups could therefore yield high returns in terms of selecting land-use options that minimize impacts on two divergent sets of values. Our results can also help structure the engagement to build consensus around shared values before exploring trade-offs for divergent values. For example, indigenous respondents and those who earn an income from agriculture were positive predictors of recreational factors (Table 4, factor 17) and both reported similar levels of importance for these factors (Fig. 4). Therefore, starting a conversation first around the importance of and strategies to protect recreational factors could help create a shared vision as a basis for then navigating potential trade-offs between biodiversity and commercial factors.

The next step in the planning process is to use our results to both inform and evaluate a range of land-use scenarios. Scenario analysis (Peterson et al. 2003) allows for the assessment of impacts of different mixes of land uses over regional extents and medium to long terms relevant to assessing cumulative impacts. Scenarios can also be used in participatory stakeholder workshops in which the different regional futures and expected changes in indicators of well-being can be explored by different groups (e.g., Carlson et al. 2011, Francis and Hamm 2011). Given the potential conflicts between different stakeholder groups over increased development, demonstrated in our analyses, a key variable to be explored in our land-use scenarios will be the level of development characterized primarily by different amounts of overall clearing. These scenarios will then be compared using an existing tool for management strategy evaluation (MSE; Pantus et al. 2011) to test how land clearing and associated water extraction affect key aspects of social, economic, and environmental well-being. For example, the abundance of fish and expected dry-season waterlevels are two measurable indices that we can relate to reported satisfaction across different stakeholder groups. The MSE tool also estimates recognized social and economic indicators such as jobs and income across different stakeholder groups. If commercial indicators increase over time, but at the expense of environmental and other indicators, these changes can be related to expected changes in satisfaction and well-being across stakeholder groups. Based on the estimated social, economic, and environmental impacts of different clearing levels on the Daly's landscapes and freshwater ecosystems, the final development targets could be refined. Further refinement of objectives and selection of a final land-use scenario will rely on engagement by either the Northern Territory Government or other appropriate advisory committees such as NTCAC.

\section{CONCLUSIONS}

Planning for multiple land uses requires navigating trade-offs between social, economic, and environmental outcomes arising from different possible futures. An important aspect of land-use planning is identifying alternative futures and building consensus among stakeholders around the best land-use options, based soundly on an understanding of perceptions of present and future well-being. This requires participation of stakeholders not only in the evaluation of potential scenarios but in the identification of explicit objectives that shape planning and scenarios. This participatory approach can be challenging, particularly for regional-scale planning that involves diverse stakeholders and complex mixes of land uses. Our analysis found different preferences between groups of residents. Being aware of these differences is an important aspect of facilitating engagement to ideally create a consensus between groups but at the very least to acknowledge that differences exist. Although our analysis focused on preferences of local residents, the result that there are divergent preferences is likely to extrapolate to other scales (e.g., regional) and our framework provides a useful way of exploring these differences.

Estimating responses of stakeholders to multiple aspects (social, economic, and environmental) of scenarios adds a further level of difficulty. Although the types of indicators being used in eliciting stakeholders' responses to scenarios have become increasingly sophisticated (e.g., social indicator developments, Mitchell and Parkins 2011), changes in indicators have not been summarized into measures of overall well-being. For example, increases in income and population size are often assumed to correlate with increases in well-being; however, depending on population preferences, these changes might not result in substantial increases in well-being if measures of environmental, social, or cultural outcomes decline (e.g., Carlson et al. 2011, Francis and Hamm 2011). Therefore, an understanding of the relative importance of different factors of well-being can contribute significantly to a more sophisticated understanding of how different land-use scenarios affect people in a region. Furthermore, measuring indicators related to well-being factors in scenario planning can make outputs more relevant to stakeholders and contribute to the overall success of participatory processes.

Responses to this article can be read online at: http://www.ecologyandsociety.org/issues/responses. $\mathrm{php} / 7168$

\section{Acknowledgments:}

This research was conducted with the support of funding from the Australian Government's National Environmental Research Program (NERP), specifically to the Northern Australia NERP Hub. RLP also acknowledges the support of the Australian Research Council Centre of Excellence for Coral Reef Studies. We thank Elizabeth Sullivan, Mona Liddy, Kathleen Parry, and Philapine Parlene for assisting with in-person interviews of indigenous residents.

\section{LITERATURE CITED}

Adams, V. M., and R. L. Pressey. 2014. Uncertainties around the implementation of a clearing-control policy in a unique catchment in Northern Australia: exploring equity issues and balancing competing objectives. PLOS ONE 9(5):e96479. http:// dx.doi.org/10.1371/journal.pone.0096479

Adams, V. M., R. L. Pressey, and N. Stoeck1. 2012. Estimating land and conservation management costs: the first step in designing a stewardship program for the Northern Territory. Biological Conservation 148:44-53. http://dx.doi.org/10.1016/j. biocon.2012.01.064 
Adams, V. M., R. L. Pressey, and N. Stoeck1. 2014. Estimating landholders' probability of participating in a stewardship program, and the implications for spatial conservation priorities. PLoS ONE 9(6):e97941. http://dx.doi.org/10.1371/journal. pone.0097941

Adams, V. M., and S. A. Setterfield. 2013. Estimating the financial risks of Andropogon gayanus to greenhouse gas abatement projects in northern Australia. Environmental Research Letters 8:025018. http://dx.doi.org/10.1088/1748-9326/8/2/025018

Ball, I. R., M. E. Watts, and H. P. Possingham. 2009. Marxan and relatives: software for spatial conservation prioritisation. Pages 185-195 in A. Moilanen, K. A. Wilson, and H. P. Possingham, editors. Spatial conservation prioritization: quantitative methods and computational tools. Oxford University Press, New York, New York, USA.

Barnaud, C., C. Le Page, P. Dumrongrojwatthana, and G. Trébuil. 2013. Spatial representations are not neutral: Lessons from a participatory agent-based modelling process in a land-use conflict. Environmental Modelling \& Software 45:150-159. http:// dx.doi.org/10.1016/j.envsoft.2011.11.016

Carlson, M. J., R. Mitchell, and L. Rodriguez. 2011. Scenario analysis to identify viable conservation strategies in Paraguay's imperiled Atlantic Forest. Ecology and Society 16(3): 8. [online] URL: http://www.ecologyandsociety.org/vol16/iss3/art8/

Convention on Biological Diversity (CBD). 2010. Aichi Biodiversity Targets. CBD, Montréal, Québec, Canada. [online] URL: http://www.cbd.int/sp/targets/

Costanza, R., R. d'Arge, R. de Groot, S. Farber, M. Grasso, B. Hannon, K. Limburg, S. Naeem, R. V. O’Neill, J. Paruelo, R. G. Raskin, P. Sutton, and M. van den Belt. 1997. The value of the world's ecosystem services and natural capital. Nature 387:253-260. http://dx.doi.org/10.1038/387253a0

Costanza, R., B. Fisher, S. Ali, C. Beer, L. Bond, R. Boumans, N. L. Danigelis, J. Dickinson, C. Elliott, J. Farley, D. E. Gayer, L. M. Glenn, T. Hudspeth, D. Mahoney, L. McCahill, B. McIntosh, B. Reed, S. A. T. Rizvi, D. M. Rizzo, T. Simpatico, and R. Snapp. 2007. Quality of life: an approach integrating opportunities, human needs, and subjective well-being. Ecological Economics 61 (2-3):267-276. http://dx.doi.org/10.1016/j.ecolecon.2006.02.023

Cummins, R. A. 2003. Normative life satisfaction: measurement issues and a homeostatic model. Social Indicators Research 64 (2):225-256. http://dx.doi.org/10.1023/A:1024712527648

Dale, A. P., R. L. Pressey, V. M. Adams, J. G. Álvarez- Romero, M. Digby, R. Dobbs, M. M. Douglas, A. Auge, M. Maughan, J. Childs, D. Hinchley, I. Lancaster, I. Perdrisat, and N. Gobius. 2014. Catchment-scale governance in Northern Australia: a preliminary evaluation. Journal of Economic and Social Policy 16 (1):Article 2. [online] URL: http://epubs.scu.edu.au/jesp/vol16/ $\underline{\text { iss } 1 / 2}$

de Groot, R. S., R. Alkemade, L. Braat, L. Hein, and L. Willemen. 2010. Challenges in integrating the concept of ecosystem services and values in landscape planning, management and decision making. Ecological Complexity 7(3):260-272. http://dx.doi. org/10.1016/j.ecocom.2009.10.006
Department of Climate Change and Energy Efficiency (DCCEE). 2011. Methodology for savanna burning. DCCEE, Canberra, Australia.

Diener, E. 2009. The science of well-being: the collected works of Ed Diener. Springer, Dordrecht, The Netherlands.

Dillman, D. A. 2007. Mail and internet surveys: the tailored design method - 2007 update. John Wiley, Hoboken, New Jersey, USA.

Fernandes, L., J. Day, A. Lewis, S. Slegers, B. Kerrigan, D. Breen, D. Cameron, B. Jago, J. Hall, D. Lowe, J. Innes, J. Tanzer, V. Chadwick, L. Thompson, K. Gorman, M. Simmons, B. Barnett, K. Sampson, G. De'ath, B. Mapstone, H. Marsh, H. Possingham, I. Ball, T. Ward, K. Dobbs, J. Aumend, D. Slater, and K. Stapleton. 2005. Establishing representative no-take areas in the Great Barrier Reef: large-scale implementation of theory on marine protected areas. Conservation Biology 19(6):1733-1744. http://dx. doi.org/10.1111/j.1523-1739.2005.00302.X

Francis, S. R., and J. Hamm. 2011. Looking forward: using scenario modeling to support regional land use planning in Northern Yukon, Canada. Ecology and Society 16(4) 18. [online] URL: http://www.ecologyandsociety.org/vol16/iss4/art18/ http:// dx.doi.org/10.5751/ES-04532-160418

Game, E. T., G. Lipsett-Moore, R. Hamilton, N. Peterson, J. Kereseka, W. Atu, M. Watts, and H. Possingham. 2011. Informed opportunism for conservation planning in the Solomon Islands. Conservation Letters 4(1):38-46. http://dx.doi.org/10.1111/ j.1755-263X.2010.00140.X

Jackson, S., M. Finn, and P. Featherston. 2012. Aquatic resource use by Indigenous Australians in two tropical river catchments: the Fitzroy River and Daly River. Human Ecology 40(6):893-908. http://dx.doi.org/10.1007/s10745-012-9518-z

Kennard, M. J., editor. 2010. Identifying high conservation value aquatic ecosystems in northern Australia. Final report for the Department of Environment, Water, Heritage and the Arts and the National Water Commission. Tropical Rivers and Coastal Knowledge (TRaCK) Commonwealth Environmental Research Facility, Charles Darwin University, Darwin, Northern Territory, Australia. [online] URL: http://track.org.au/publications/ registry/track 843

Knight, A. T., R. M. Cowling, and B. M. Campbell. 2006. An operational model for implementing conservation action. Conservation Biology 20(2):408-419. http://dx.doi.org/10.1111/ j.1523-1739.2006.00305.x

Kristoffersen, I. 2010. The metrics of subjective wellbeing: cardinality, neutrality and additivity. Economic Record 86 (272):98-123. http://dx.doi.org/10.1111/j.1475-4932.2009.00598. $\underline{\mathrm{x}}$

Larson, S. 2009. Communicating stakeholder priorities in the Great Barrier Reef region. Society \& Natural Resources 22 (7):650-664. http://dx.doi.org/10.1080/08941920801992102

Larson, S. 2010. Regional well-being in tropical Queensland, Australia: developing a dissatisfaction index to inform government policy. Environment and Planning 42(12):2972-2989. http://dx.doi.org/10.1068/a43193 
Larson, S., and K. Alexandridis. 2009. Socio-economic profiling of tropical rivers. Land and Water Australia, Canberra, Australia.

Larson, S., N. Stoeckl, B. Neil, and R. Welters. 2013. Using resident perceptions of values associated with the Australian tropical rivers to identify policy and management priorities. Ecological Economics 94:9-18. $\quad$ http://dx.doi.org/10.1016/j. ecolecon.2013.07.005

Malinga, R., L. J. Gordon, R. Lindborg, and G. Jewitt. 2013. Using participatory scenario planning to identify ecosystem services in changing landscapes. Ecology and Society 18(4): 10. [online] URL: http://www.ecologyandsociety.org/vol18/iss4/ art10/ http://dx.doi.org/10.5751/ES-05494-180410

Marans, R. W. 2003. Understanding environmental quality through quality of life studies: the 2001 DAS and its use of subjective and objective indicators. Landscape and Urban Planning 65(1-2):73-83. http://dx.doi.org/10.1016/S0169-2046 (02)00239-6

Margules, C. R., and R. L. Pressey. 2000. Systematic conservation planning. Nature 405:243-253. http://dx.doi.org/10.1038/35012251

Maynard, S., D. James, and A. Davidson. 2010. The development of an ecosystem services framework for South East Queensland. Environmental Management 45(5):881-895. http://dx.doi.org/10.1007/ $\underline{\mathrm{s} 00267-010-9428-\mathrm{Z}}$

McShane, T. O., P. D. Hirsch, T. C. Trung, A. N. Songorwa, A. Kinzig, B. Monteferri, D. Mutekanga, H. V. Thang, J. L. Dammert, M. Pulgar-Vidal, M. Welch-Devine, J. P. Brosius, P. Coppolillo, and S. O'Connor. 2011. Hard choices: making tradeoffs between biodiversity conservation and human well-being. Biological Conservation 144(3):966-972. http://dx.doi.org/10.1016/ j.biocon.2010.04.038

Millennium Ecosystem Assessment. 2005. Ecosystems and human well-being: synthesis. Island Press, Washington, D.C., USA.

Mitchell, R. E., and J. R. Parkins. 2011. The challenge of developing social indicators for cumulative effects assessment and land use planning. Ecology and Society 16(2) 29. [online] URL: http://www.ecologyandsociety.org/vol16/iss2/art29/

Northern Territory Department of Natural Resources, Environment, The Arts and Sport (NRETAS). 2010. Land clearing guidelines. NRETAS, Palmerston, Northern Territory, Australia.[online] URL: http://www.lrm.nt.gov.au/ data/assets/ pdf_file/0018/5526/NT-Land-Clearing-Guidelines-2010_040310_UpdatedApril-2013.pdf

Pantus, F. J., C. L. Barton, L. Bradford, and M. Stroet. 2011. Integrated science support for managing Australia's tropical rivers: a case study in the Daly river catchment. Tropical Rivers \& Coastal Knowledge Research Hub, Charles Darwin University, Darwin, Northern Territory, Australia. [online] URL: http://www.track. org.au/publications/registry/track 956

Pascoe-Bell, A., B. Lynch, J. Hill, C. Green, A. Cameron, and S. Smith. 2011. Identification of potential land for long-term sustainable food production. Department of Natural Resources, Environment, The Arts and Sport (NRETAS), Palmerston, Northern Territory, Australia.
Peterson, G. D., G. S. Cumming, and S. R. Carpenter. 2003. Scenario planning: a tool for conservation in an uncertain world. Conservation Biology 17(2):358-366. http://dx.doi.org/10.1046/ j.1523-1739.2003.01491.x

Polasky, S., E. Nelson, J. Camm, B. Csuti, P. Fackler, E. Lonsdorf, C. Montgomery, D. White, J. Arthur, B. Garber-Yonts, R. Haight, J. Kagan, A. Starfield, and C. Tobalske. 2008. Where to put things? Spatial land management to sustain biodiversity and economic returns. Biological Conservation 141(6):1505-1524. http://dx.doi. org/10.1016/j.biocon.2008.03.022

Polasky, S., E. Nelson, E. Lonsdorf, P. Fackler, and A. Starfield. 2005. Conserving species in a working landscape: land use with biological and economic objectives. Ecological Applications 15 (4):1387-1401. http://dx.doi.org/10.1890/03-5423

Pressey, R. L., and M. C. Bottrill. 2009. Approaches to landscapeand seascape-scale conservation planning: convergence, contrasts and challenges. Oryx 43(4):464-475. http://dx.doi.org/10.1017/ $\underline{\mathrm{S} 0030605309990500}$

Pressey, R. L., M. Mills, R. Weeks, and J. C. Day. 2013. The plan of the day: managing the dynamic transition from regional conservation designs to local conservation actions. Biological Conservation 166:155-169. http://dx.doi.org/10.1016/j.biocon.2013.06.025

Salter, J. D., C. Campbell, M. Journeay, and S. R. J. Sheppard. 2009. The digital workshop: exploring the use of interactive and immersive visualisation tools in participatory planning. Journal of Environmental Management 90(6):2090-2101. http://dx.doi. org/10.1016/j.jenvman.2007.08.023

Stoeckl, N., S. Jackson, F. Pantus, M. Finn, M. J. Kennard, and B. J. Pusey. 2013. An integrated assessment of financial, hydrological, ecological and social impacts of 'development' on Indigenous and non-Indigenous people in northern Australia. Biological Conservation 159:214-221. http://dx.doi.org/10.1016/j. biocon.2012.12.007

Summers, J. K., L. M. Smith, J. L. Case, and R. A. Linthurst. 2012. A review of the elements of human well-being with an emphasis on the contribution of ecosystem services. Ambio 41 (4):327-340. http://dx.doi.org/10.1007/s13280-012-0256-7

Syakur, A., J. T. Wibowo, F. Firmansyah, I. Azam, and M. Linkie. 2012. Ensuring local stakeholder support for marine conservation: establishing a locally-managed marine area network in Aceh. Oryx 46(4):516-524. http://dx.doi.org/10.1017/ S0030605312000166

Tallis, H., P. Kareiva, M. Marvier, and A. Chang. 2008. An ecosystem services framework to support both practical conservation and economic development. Proceedings of the National Academy of Sciences of the United States of America 105(28):9457-9464. http://dx.doi.org/10.1073/pnas.0705797105

Venter, O., H. P. Possingham, L. Hovani, S. Dewi, B. Griscom, G. Paoli, P. Wells, and K. A. Wilson. 2013. Using systematic conservation planning to minimize REDD+ conflict with agriculture and logging in the tropics. Conservation Letters 6:116-124. http://dx.doi.org/10.1111/j.1755-263X.2012.00287.x

Watts, M. E., I. R. Ball, R. S. Stewart, C. J. Klein, K. Wilson, C. Steinback, R. Lourival, L. Kircher, and H. P. Possingham. 2009. 
Marxan with zones: software for optimal conservation-based land- and sea-use zoning. Environmental Modelling \& Software 24:1513-1521. http://dx.doi.org/10.1016/j.envsoft.2009.06.005

Weber, M., N. Krogman, and T. Antoniuk. 2012. Cumulative effects assessment: linking social, ecological, and governance dimensions. Ecology and Society 17(2): 22. [online] URL: http:// www.ecologyandsociety.org/vol17/iss2/art22/ http://dx.doi.org/10.5751/ ES-04597-170122

Wilson, K. A., E. Meijaard, S. Drummond, H. S. Grantham, L. Boitani, G. Catullo, L. Christie, R. Dennis, I. Dutton, A. Falcucci, L. Maiorano, H. P. Possingham, C. Rondinini, W. R. Turner, O. Venter, and M. Watts. 2010. Conserving biodiversity in production landscapes. Ecological Applications 20(6):1721-1732. http://dx.doi.org/10.1890/09-1051.1

Woodward, E., S. Jackson, M. Finn, and P. M. McTaggart. 2012. Utilising Indigenous seasonal knowledge to understand aquatic resource use and inform water resource management in northern Australia. Ecological Management \& Restoration 13(1):58-64. http://dx.doi.org/10.1111/j.1442-8903.2011.00622.x

Zander, K. K., S. T. Garnett, and A. Straton. 2010. Trade-offs between development, culture and conservation - willingness to pay for tropical river management among urban Australians. Journal of Environmental Management 91(12):2519-2528. http:// dx.doi.org/10.1016/j.jenvman.2010.07.012

Zander, K. K., R. Parkes, A. Straton, and S. T. Garnett. 2013. Water ecosystem services in Northern Australia-How much are they worth and who should pay for their provision? PLOS ONE 8(5):e64411. http://dx.doi.org/10.1371/journal.pone.0064411

Zander, K. K., and A. Straton. 2010. An economic assessment of the value of tropical river ecosystem services: Heterogeneous preferences among Aboriginal and non-Aboriginal Australians. Ecological Economics 69(12):2417-2426. http://dx.doi.org/10.1016/ j.ecolecon.2010.07.010 
Appendix 1. Survey.

\section{Dear Landholder}

We are developing a regional Conservation and Development Plan for the Daly catchment, and results will be used to advise the Daly River Management Committee and Northern Territory Government on strategically managing the Daly River Catchment - for both development and conservation.

As part of the planning process we are trying to find out more about:

- How the environment affects people's health and well-being.

- How satisfied or dissatisfied you are with the environment and potential changes in the environment in the Daly.

- How you would like to use your land.

This research is important because it allows us to understand what is most important to catchment residents, what changes they would like to see both on their properties and in the catchment, and what aspects of their lives in the catchment they would like to stay the same.

The questionnaire should take you about 15-20 minutes to complete. We hope you will agree to participate. This survey is a chance to have your say in the plan. It is important that the plan reflect all residents' values and preferences for the catchment. If you agree to participate, you can complete the survey a few different ways:

1) You can complete the questionnaire (enclosed) and mail it back in the enclosed reply-paid envelope.

2) You can call me. I am happy to chat to you about the project; and I am happy to complete the survey over the phone (at a time that is convenient for you), to save you having to fill in the questionnaire yourself.

3) You can complete the survey online

We are asking all residents in the Daly River Catchment to assist. Taking part in this study is completely voluntary and you do not need to answer all questions. You can stop at any time without explanation or prejudice. You can also ask us to withdraw any unprocessed data from the study. All data will be de-identified so that names and places are kept separate to research answers, and data will only be released in 'aggregate' form (e.g. saying that the 'average' resident said ....), so that it is impossible for anyone to work out 'who said what'.

If you have any questions about the project, or if you are interested in seeing the results, then please feel free to contact me.

With many thanks. 
First, we would like to collect some information about where you go and what you do in and around the Daly Catchment.

The Daly Catchment is $\sim 250 \mathrm{~km}$ south of Darwin and spans more than 5 million hectares. The Daly River is a perennial river and the region supports a number of industries. There are national parks and the region has a range of recreational and cultural values.

1. Do you live in the Daly Catchment?

$\square$ yes, please specify your property

no, please specify your postcode

2. Have you ever been to any of the national parks, rivers, swimming holes or wetlands in the Daly?
$\square$ yes
$\square$ no
if no, go to question 7 (page 2)

Now we'd like to find out about where you go in the Daly.

3. Please tell us how often you do each of the following in the Daly by ticking one box in each row of the table below:

\begin{tabular}{|c|c|c|c|c|c|c|c|}
\hline & $\begin{array}{l}\text { Almost } \\
\text { every day }\end{array}$ & $\begin{array}{l}\text { A few } \\
\text { times a } \\
\text { month }\end{array}$ & $\begin{array}{l}\text { About } \\
\text { once a } \\
\text { month }\end{array}$ & $\begin{array}{c}\text { 3-4 } \\
\text { times a } \\
\text { year }\end{array}$ & $\begin{array}{c}\text { About } \\
\text { once a } \\
\text { year }\end{array}$ & Rarely & Never \\
\hline Spend time in the national parks & $\square$ & $\square$ & $\square$ & $\square$ & $\square$ & $\square$ & $\square$ \\
\hline Spend time on a private property & $\square$ & $\square$ & $\square$ & $\square$ & $\square$ & $\square$ & $\square$ \\
\hline Boating, camping, swimming in the Daly Region & $\square$ & $\square$ & $\square$ & $\square$ & $\square$ & $\square$ & $\square$ \\
\hline Boating, camping, swimming in Katherine & $\square$ & $\square$ & $\square$ & $\square$ & $\square$ & $\square$ & $\square$ \\
\hline Fishing on the Daly & $\square$ & $\square$ & $\square$ & $\square$ & $\square$ & $\square$ & $\square$ \\
\hline Fishing on other rivers & $\square$ & $\square$ & $\square$ & $\square$ & $\square$ & $\square$ & $\square$ \\
\hline Other (please tells us what this is) & $\square$ & $\square$ & $\square$ & $\square$ & $\square$ & $\square$ & $\square$ \\
\hline
\end{tabular}

4. Compared to other things you like doing in your free time (like going to the movies, playing sport, etc), how important are the things you do in the Daly? (Please give a score between 0 and 10 - with 0 meaning Daly activities are very unimportant (compared to other things) and 10 meaning they are extremely important)

5. Now please show us your favourite place in the Daly (this does not have to be the place you go to most often) by marking it on the map. So we know exactly where this is, we would also like you to give us a little more information about that place below (e.g. the campsite at Butterfly Gorge).

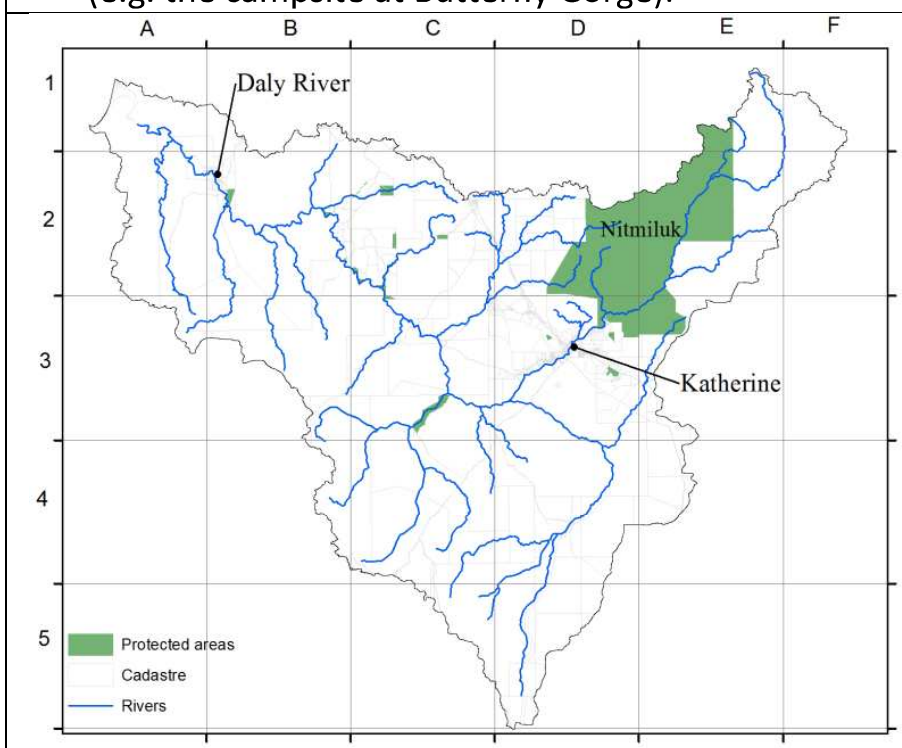

My favourite place is...
6. Is there anywhere in the Daly that you would like to see protected? If so please mark on the map and give us a little bit more information about the place below.

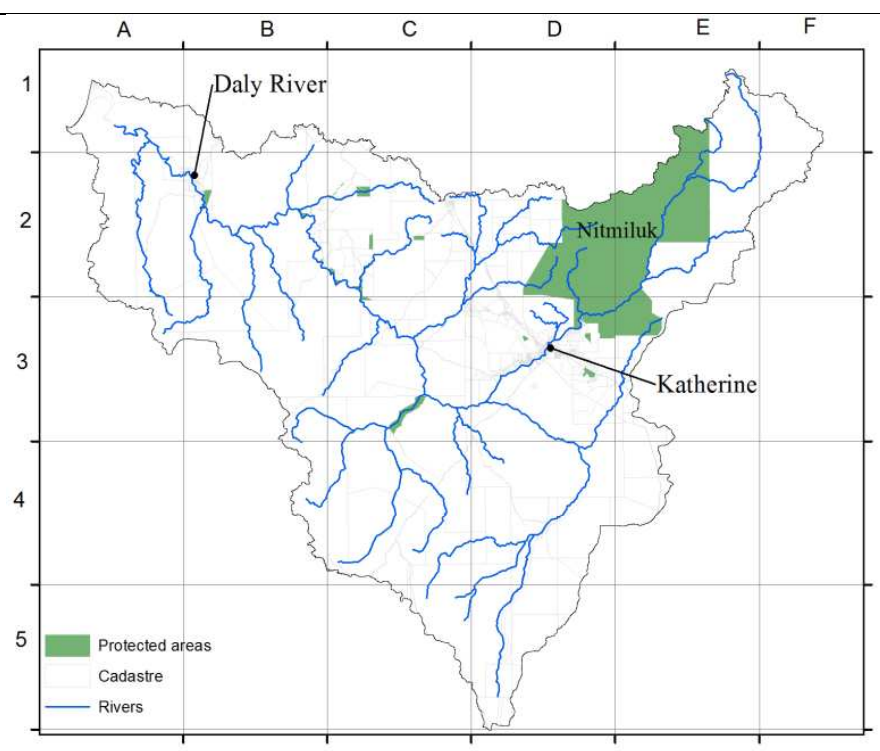

I think should be protected

because... 
Now we would like to find out what you think is most (and least) important about the Daly, and if you have any concerns about those 'things'.

7. First, to provide us with some background context, please think about your own life and personal circumstances. On a scale of 0 to 10 , how satisfied are you with your life as a whole $(0=$ Very Unsatisfied; $10=$ Completely Satisfied $)$ ?

8. The table below gives a list of the things which some people think are important about the Daly Catchment (you will be able to add others). Please complete the table, telling us how important each item is to you personally and also how satisfied you are with its current status/condition (or is something 'wrong'?).

\begin{tabular}{|c|c|c|c|c|c|}
\hline & \multicolumn{2}{|c|}{$\begin{array}{l}\text { On a scale of } 0 \text { to } 10 \text {, how } \\
\text { important are these things to your } \\
\text { own personal well-being? }\end{array}$} & \multicolumn{2}{|c|}{$\begin{array}{c}\text { On a scale of } 0 \text { to } 10, \text { how } \\
\text { satisfied are you with these } \\
\text { things in the Daly }\end{array}$} \\
\hline & & $\begin{array}{l}(0=\text { Not important at all; } \\
10=\text { Extremely } \\
\text { important/ESSENTIAL) }\end{array}$ & $\begin{array}{l}\text { Not } \\
\text { Sure }\end{array}$ & $\begin{array}{c}\text { ( } 0 \text { = Completely } \\
\text { dissatisfied/unhappy; } \\
10=\text { Completely Satisfied) }\end{array}$ & $\begin{array}{l}\text { Not } \\
\text { Sure }\end{array}$ \\
\hline 1 & $\begin{array}{l}\text { The river provides habitat for iconic species (like barramundi, } \\
\text { black bream, long-neck turtles, sawfish) }\end{array}$ & & $\square$ & & $\square$ \\
\hline 2 & $\begin{array}{l}\text { The catchment provides habitat to a variety of plants and } \\
\text { animals }\end{array}$ & & $\square$ & & $\square$ \\
\hline 3 & A place where the river flows naturally and there are no dams & & $\square$ & & $\square$ \\
\hline 4 & $\begin{array}{l}\text { A place for natural heritage (e.g. important National Parks and } \\
\text { unique environments) }\end{array}$ & & $\square$ & & $\square$ \\
\hline 5 & A place for diverse development and intensified production & & $\square$ & & $\square$ \\
\hline 6 & $\begin{array}{l}\text { The tourism industry in the catchment provides jobs and } \\
\text { income }\end{array}$ & & $\square$ & & $\square$ \\
\hline 7 & $\begin{array}{l}\text { The agricultural industry in the catchment provides jobs and } \\
\text { income }\end{array}$ & & $\square$ & & $\square$ \\
\hline 8 & $\begin{array}{l}\text { The mining industry in the catchment provides jobs and } \\
\text { income }\end{array}$ & & $\square$ & & $\square$ \\
\hline 9 & The cattle industry in the catchment provides jobs and income & & $\square$ & & $\square$ \\
\hline 10 & $\begin{array}{l}\text { The forestry industry in the catchment provides jobs and } \\
\text { income }\end{array}$ & & $\square$ & & $\square$ \\
\hline 11 & $\begin{array}{l}\text { A place that is relatively free from congestion and major } \\
\text { development }\end{array}$ & & $\square$ & & $\square$ \\
\hline 12 & A place that supports families and communities & & $\square$ & & $\square$ \\
\hline 13 & A place to preserve traditional (e.g. Indigenous) cultural values & & $\square$ & & $\square$ \\
\hline 14 & A place for research, teaching and learning & & $\square$ & & $\square$ \\
\hline 15 & $\begin{array}{l}\text { It is important to keep the area in good condition for future } \\
\text { generations }\end{array}$ & & $\square$ & & $\square$ \\
\hline 16 & $\begin{array}{l}\text { Even if I could never visit ANY part of the Daly, I would still like } \\
\text { to know 'it is there' }\end{array}$ & & $\square$ & & $\square$ \\
\hline 17 & Fishing and hunting for fun & & $\square$ & & $\square$ \\
\hline 18 & Swimming, camping, boating, being on country & & $\square$ & & $\square$ \\
\hline 19 & Fishing and hunting for fresh food & & $\square$ & & $\square$ \\
\hline 20 & $\begin{array}{l}\text { If this list does not include things important to you, please list } \\
\text { them here ......... }\end{array}$ & & $\square$ & & $\square$ \\
\hline
\end{tabular}

9. Please tell us which of these items you think is THE MOST IMPORTANT, by circling the number beside it. If the list does not include your 'most important thing' (about the Daly), please tell us what it is:

10. Are any of these things listed in the table so important to you that you would move to another part of Australia (or the world) if it were not here?
$\square$ No
$\square$ Yes
Which things? Please write here the number of the statement so we know what it is.

11. Please tell us which of the things in question 8 you are most dissatisfied/unhappy with and WHY.

Most dissatisfied with:

Because: 
12. Now, please tell us how each of the changes listed below would affect your overall satisfaction with life by ticking one box in each row

\begin{tabular}{|c|c|c|c|c|c|c|c|c|c|c|c|}
\hline \multirow{2}{*}{$\begin{array}{l}\text { Type of 'change' } \\
\text { If the cost of living rose by } 20 \% \text { (compared to other } \\
\text { places in Australia) }\end{array}$} & \multirow{2}{*}{$\begin{array}{c}\text { I do } \\
\text { not } \\
\text { know } \\
\square\end{array}$} & \multicolumn{3}{|c|}{$\begin{array}{l}\text { I would be } \\
\text { much more } \\
\text { satisfied }\end{array}$} & \multicolumn{3}{|c|}{$\begin{array}{l}\text { Not at all } \\
\text { affected }\end{array}$} & \multicolumn{3}{|c|}{$\begin{array}{l}\text { I would be } \\
\text { much more } \\
\text { dissatisfied }\end{array}$} & \multirow{2}{*}{$\begin{array}{l}\text { I would be so dissatisfied } \\
\text { I would move to some } \\
\text { other part of Australia (or } \\
\text { the world) } \\
\square\end{array}$} \\
\hline & & $\square$ & $\square$ & $\square$ & $\square$ & $\square$ & $\square$ & $\square$ & $\square$ & $\square$ & \\
\hline $\begin{array}{l}\text { If there were twice as much infrastructure to support } \\
\text { communities (e.g. sealed roads, schools, electricity) }\end{array}$ & $\square$ & $\square$ & $\square$ & $\square$ & $\square$ & $\square$ & $\square$ & $\square$ & $\square$ & $\square$ & $\square$ \\
\hline $\begin{array}{l}\text { If the water level in the Daly dropped significantly in the } \\
\text { dry season }\end{array}$ & $\square$ & $\square$ & $\square$ & $\square$ & $\square$ & $\square$ & $\square$ & $\square$ & $\square$ & $\square$ & $\square$ \\
\hline $\begin{array}{l}\text { If there were half as many fish to catch in the Daly } \\
\text { (fewer fish, and less variety) }\end{array}$ & $\square$ & $\square$ & $\square$ & $\square$ & $\square$ & $\square$ & $\square$ & $\square$ & $\square$ & $\square$ & $\square$ \\
\hline If there was twice as much agriculture & $\square$ & $\square$ & $\square$ & $\square$ & $\square$ & $\square$ & $\square$ & $\square$ & $\square$ & $\square$ & $\square$ \\
\hline If there was twice as much mining & $\square$ & $\square$ & $\square$ & $\square$ & $\square$ & $\square$ & $\square$ & $\square$ & $\square$ & $\square$ & 口 \\
\hline If there were twice as many tourists & $\square$ & $\square$ & $\square$ & $\square$ & $\square$ & $\square$ & $\square$ & $\square$ & $\square$ & $\square$ & $\square$ \\
\hline $\begin{array}{l}\text { If there were twice as many people living in the } \\
\text { Catchment }\end{array}$ & $\square$ & $\square$ & $\square$ & $\square$ & $\square$ & $\square$ & $\square$ & $\square$ & $\square$ & $\square$ & $\square$ \\
\hline If there were half as many trees & $\square$ & $\square$ & $\square$ & $\square$ & $\square$ & $\square$ & $\square$ & $\square$ & $\square$ & $\square$ & $\square$ \\
\hline $\begin{array}{l}\text { If there were half as many places to visit for camping, } \\
\text { swimming, fishing }\end{array}$ & $\square$ & $\square$ & $\square$ & $\square$ & $\square$ & $\square$ & $\square$ & $\square$ & $\square$ & $\square$ & $\square$ \\
\hline If there was half as much agriculture & $\square$ & $\square$ & $\square$ & $\square$ & $\square$ & $\square$ & $\square$ & $\square$ & $\square$ & $\square$ & $\square$ \\
\hline If there was half as much mining & $\square$ & $\square$ & $\square$ & $\square$ & $\square$ & $\square$ & $\square$ & $\square$ & $\square$ & $\square$ & $\square$ \\
\hline If there were half as many tourists & $\square$ & $\square$ & $\square$ & $\square$ & $\square$ & $\square$ & $\square$ & $\square$ & $\square$ & $\square$ & $\square$ \\
\hline $\begin{array}{l}\text { If there were half as many people living in the } \\
\text { Catchment }\end{array}$ & $\square$ & $\square$ & $\square$ & $\square$ & $\square$ & $\square$ & $\square$ & $\square$ & $\square$ & $\square$ & $\square$ \\
\hline If there were twice as many trees & $\square$ & $\square$ & $\square$ & $\square$ & $\square$ & $\square$ & $\square$ & $\square$ & $\square$ & $\square$ & $\square$ \\
\hline $\begin{array}{l}\text { If there was twice as many fish to catch in the Daly } \\
\text { (more fish) }\end{array}$ & $\square$ & $\square$ & $\square$ & $\square$ & $\square$ & $\square$ & $\square$ & $\square$ & $\square$ & $\square$ & $\square$ \\
\hline If there was a dam on the Daly River & $\square$ & $\square$ & $\square$ & $\square$ & $\square$ & $\square$ & $\square$ & $\square$ & $\square$ & $\square$ & $\square$ \\
\hline
\end{tabular}

13. Now thinking about clearing in the Daly, please consider if everyone cleared their properties by the same percentage how this change in clearing across the catchment would affect your overall satisfaction with life by ticking one box in each row

\begin{tabular}{|c|c|c|c|c|c|c|c|c|c|c|c|}
\hline \multirow{2}{*}{$\begin{array}{l}\text { Type of 'change' } \\
\text { Everyone cleared } 10 \% \text { of their property }\end{array}$} & \multirow{2}{*}{$\begin{array}{l}\text { I do not } \\
\text { know } \\
\square\end{array}$} & \multicolumn{3}{|c|}{$\begin{array}{l}\text { I would be } \\
\text { much more } \\
\text { satisfied }\end{array}$} & \multicolumn{3}{|c|}{$\begin{array}{l}\text { Not at all } \\
\text { affected }\end{array}$} & \multicolumn{3}{|c|}{$\begin{array}{l}\text { I would be } \\
\text { much more } \\
\text { dissatisfied }\end{array}$} & \multirow{2}{*}{$\begin{array}{l}\text { I would be so dissatisfied } \\
\text { I would move to some } \\
\text { other part of Australia (or } \\
\text { the world) } \\
\square\end{array}$} \\
\hline & & $\square$ & $\square$ & $\square$ & $\square$ & $\square$ & $\square$ & $\square$ & $\square$ & $\square$ & \\
\hline Everyone cleared $\mathbf{2 0} \%$ of their property & $\square$ & $\square$ & $\square$ & $\square$ & $\square$ & $\square$ & $\square$ & $\square$ & $\square$ & $\square$ & $\square$ \\
\hline Everyone cleared $\mathbf{3 0} \%$ of their property & $\square$ & $\square$ & $\square$ & $\square$ & $\square$ & $\square$ & $\square$ & $\square$ & $\square$ & $\square$ & $\square$ \\
\hline Everyone cleared $\mathbf{4 0 \%}$ of their property & $\square$ & $\square$ & $\square$ & $\square$ & $\square$ & $\square$ & $\square$ & $\square$ & $\square$ & $\square$ & $\square$ \\
\hline Everyone cleared $\mathbf{5 0 \%}$ of their property & $\square$ & $\square$ & $\square$ & $\square$ & $\square$ & $\square$ & $\square$ & $\square$ & $\square$ & $\square$ & $\square$ \\
\hline Everyone cleared $60 \%$ of their property & $\square$ & $\square$ & $\square$ & $\square$ & $\square$ & $\square$ & $\square$ & $\square$ & $\square$ & $\square$ & $\square$ \\
\hline Everyone cleared $\mathbf{7 0} \%$ of their property & $\square$ & $\square$ & $\square$ & $\square$ & $\square$ & $\square$ & $\square$ & $\square$ & $\square$ & $\square$ & $\square$ \\
\hline Everyone cleared $\mathbf{8 0} \%$ of their property & $\square$ & $\square$ & $\square$ & $\square$ & $\square$ & $\square$ & $\square$ & $\square$ & $\square$ & $\square$ & $\square$ \\
\hline Everyone cleared $\mathbf{9 0 \%}$ of their property & $\square$ & $\square$ & $\square$ & $\square$ & $\square$ & $\square$ & $\square$ & $\square$ & $\square$ & $\square$ & $\square$ \\
\hline Everyone cleared $100 \%$ of their property & $\square$ & $\square$ & $\square$ & $\square$ & $\square$ & $\square$ & $\square$ & $\square$ & $\square$ & $\square$ & $\square$ \\
\hline
\end{tabular}


Now, we'd like to ask you a few questions about how you currently use your property and what plans you have for development on your land.

14. How many years have you owned/managed this property?

15. Which of the following best describes the legal tenure of your land?

$\square$ Land under Native Title

$\square$ Land under an Indigenous Land-Use agreement

$\square$ Freehold

$\square$ Leasehold, if at least some of the land is leasehold, please tell us

a) Roughly what \% is leasehold $\%$

b) How long until the lease expires? years

Other (please specify)

16. What is the total area of your land? (hectares)

17. On your property, approximately how many hectares ......?

Had been cleared about 5 years ago? (hectares)

Are now cleared? (hectares)

Would you like to have cleared in about 5 years from now? (hectares)

18. For each of the following 'activities', please tell us how many hectares of your land (a) had the following uses about 5 years ago; (b) have the following uses now; and (c) you would like to be under the following uses in about 5 years?

\begin{tabular}{|l|l|l|l|}
\hline Activity/Purpose & $\begin{array}{c}\text { Hectares used for } \\
\text { this } 5 \text { years ago }\end{array}$ & $\begin{array}{c}\text { Hectares used for } \\
\text { this now }\end{array}$ & $\begin{array}{c}\text { Hectares you would } \\
\text { like to use for this in } \\
\text { about } \mathbf{5} \text { years }\end{array}$ \\
\hline Livestock - native vegetation & & & \\
\hline Livestock - irrigated pastures & & & \\
\hline Livestock - non irrigated pastures & & & \\
\hline Cropping - irrigated & & & \\
\hline Cropping - non irrigated & & & \\
\hline Horticulture - irrigated & & & \\
\hline Horticulture - non irrigated & & & \\
\hline $\begin{array}{l}\text { Forestry } \\
\text { Mining exploration or lease }\end{array}$ & & & \\
\hline $\begin{array}{l}\text { Conservation of wetlands (with livestock } \\
\text { excluded) }\end{array}$ & & & \\
\hline $\begin{array}{l}\text { Conservation of riparian strips (with livestock } \\
\text { excluded) }\end{array}$ & & \\
\hline $\begin{array}{l}\text { Conservation, revegetation or restoration of other } \\
\text { habitats. Please tell us (e.g. revegetation of native } \\
\text { forest)................ }\end{array}$ & & \\
\hline
\end{tabular}


Finally, we would like to collect some more background about you and your household. This will allow us to make sure that we have collected information from a wide variety of people and to test if different people (e.g. males or those who recently moved to the region) feel differently about the Daly.

19. Are you $\square$ Male $\square$ Female

20. What is your marital status? $\square$ single $\square$ Married $\square$ other

21. In what year were you born? 19

22. Where were you born?

$\square$ Overseas (please tell us which country)

$\square$ Australia (please tell us which town)

23. How long have you lived at this address?

$$
\text { Years. }
$$

If less than five years, where did you live before you moved here?

Overseas (please tell us which country)

Australia (please tell us which postcode)

24. How many people, including yourself, normally live with you? (please give the number)

Does that include any children under the age of 16 years?

$\square$ no

$\square$ yes $\longrightarrow$ How many

Are you or any of the people who normally live with you Aboriginal or Torres Strait Islanders?

$\square$ Yes (Aboriginal) $\quad \square$ Yes (Torres Strait Islander)

$\square$ No

25. What is the highest level of education that you have completed? (Please tick)

$\square$ Primary school $\square$ University

$\square$ High school (year 10) $\square$ Trade / apprenticeship

$\square$ High school (year 12) $\square$ Other (please specify)

26. Which of these best describes your occupation? (please tick box)
$\square$ Self-employed
$\square$ Student
$\square$ Employed - Full time
$\square$ Retiree
$\square$ Employed - Part time or casual
$\square$ At-home duties

27. Have you recently been involved in community activities or voluntary work (such as sporting clubs, school activities, church, etc?) Please list here:

28. Do you belong to any industry or professional association or other organisation? If yes, please list here:

29. Please indicate which of the industries listed below is the main source (i.e. most important source) of your household's income? (please tick one)

$\square$ Retail (e.g. food shops)

$\square$ Construction or other trade (eg electrician, plumber, builder etc)

$\square$ Manufacturing

$\square$ Environmental protection / management

$\square$ Mining

$\square$ Transport

Tourism

Agriculture: fruit, nuts, vegetables or other horticulture

$\square$ Agriculture: livestock (pastoral / open grazing)

$\square$ Agriculture: forestry

$\square$ other private sector service (such as hairdresser, shop assistant, etc, please specify):

Ggovernment or government service (such as teacher, Council worker etc, please specify) Receiving support from government

$\begin{array}{ll}\square \text { pension } & \square \text { unemployment benefits } \\ \square \text { CDEP } & \square \text { Austudy, Abstudy or similar }\end{array}$

OR: Earning income from some other source:

$\square$ income from investment/ private pension (including Superannuation)

$\square$ support from family/friends $\square$ other: (please specify)

OR:

$\square$ None of these industries (our household earns most of its money from other sources)

30. On average, how much (before tax) income does your household earn each year? Please include your income, and also the income of the other people in your household/family (i.e. the ones you live with and share expenses with). (Please tick)

$\square \$ 1$ to $\$ 20000$

$\square \$ 20000$ to $\$ 35000$

$\$ 35000$ to $\$ 50000$

$\$ 50000$ to $\$ 75000$

$\square \$ 75000$ to $\$ 100000$ $\square \$ 100000$ to $\$ 150000$

$\square \$ 150000$ and $\$ 200000$

$\square$ above $\$ 200,000$

$\square$ prefer not to specify

$\square$ don't know 